\title{
Activated carbon produced from Glycyrrhiza glabra residue for the adsorption of nitrate and phosphate: batch and fixed-bed column studies
}

\author{
Sanaz Najmi ${ }^{1} \cdot$ Mohammad Sadegh Hatamipour $^{1}$ (D) Pegah Sadeh ${ }^{2} \cdot$ Iman Najafipour $^{1} \cdot$ Fahimeh Mehranfar $^{3}$
}

Received: 17 December 2019 / Accepted: 23 March 2020 / Published online: 28 March 2020

(c) Springer Nature Switzerland AG 2020

\begin{abstract}
In the present study, Glycyrrhiza glabra residues (GGR) were used for the preparation of activated carbon, with a surface area of $959.22 \mathrm{~m}^{2} \mathrm{~g}^{-1}$. Activated carbon was prepared through chemical activation using $\mathrm{ZnCl}_{2}$ at optimum carbonization temperature, and impregnation ratio for nitrate, and phosphate removal. The effect of contact time and adsorbent dosage on the removal efficiency was investigated, and the pseudo-second-order kinetic model correlated well with the adsorption data. The response surface methodology was applied for the determination of the effect of initial concentration, $\mathrm{pH}$, and temperature and their interaction on the removal efficiency in the batch adsorption system. The Langmuir isotherm generated a satisfactory fit with the experimental data, and the maximum adsorption capacity was $142.5 \mathrm{mg} \mathrm{g}^{-1}$ at $308 \mathrm{~K}_{\text {and }} 92.5 \mathrm{mg} \mathrm{g}^{-1}$ at $298 \mathrm{~K}$ for nitrate and phosphate removal, respectively. The high adsorption capacity reveals the applicability of the GGR activated carbon for nitrate and phosphate removal. Furthermore, the fixed-bed column adsorption studies were carried out, and the effect of flow rate and influent concentration on the behavior of the breakthrough curve was studied. The breakthrough time decreased by increasing the flow rate and inlet concentration. The Thomas and Yoon-Nelson models were suitable models for the design of GGR activated carbon fixed-bed column. The LUB of $0.44 \mathrm{~cm}$ and $4.35 \mathrm{~cm}$ was obtained for nitrate and phosphate with the inlet concentration of $20 \mathrm{mg} \mathrm{L}^{-1}$ and a flow rate of $40 \mathrm{~mL} \mathrm{~min}{ }^{-1}$, respectively. GGR is a new adsorbent that has not been previously utilized for adsorption of phosphate and nitrate.
\end{abstract}

Keywords Glycyrrhiza glabra residue activated carbon · Nitrate removal · Phosphate adsorption · RSM · Fixed-bed column adsorption

\section{Introduction}

Urbanization, industrialization, high usage of agricultural fertilizers, combined with inappropriate treatment of wastewater, have led to contamination of the environment and groundwater resources by toxic pollutants including organic, and inorganic ions like nitrate and phosphate. Nitrogen and phosphorous are used in agriculture due to their high solubility in water and nutritious values for the plants [1-3]. However, excessive release of nitrate and phosphate to the environment adversely affects the ecosystem and human health $[4,5]$. Nitrate can cause several serious health problems including respiratory tract infection, diarrhea, hypertension, and blue baby syndrome for infants $[3,6]$. Furthermore, nitrate could change to nitrite, a carcinogenic compound that increases the risk of cancer, and could potentially leach out from the soil to water, thus polluting the drinking water resources $[2,7]$. Phosphate

$\varangle$ Mohammad Sadegh Hatamipour, hatami@eng.ui.ac.ir| ${ }^{1}$ Department of Chemical Engineering, College of Engineering, University of Isfahan, P.O. Box 81746-73441, Isfahan, Iran. ${ }^{2}$ Chemical Engineering Discipline, School of Engineering, Monash University, Melbourne, Malaysia. ${ }^{3}$ Central Laboratory, Isfahan Water and Wastewater Company, Isfahan, Iran. 
can lead to the formation of algal blooms, which could endanger human health by the production of cyanotoxins [8]. Phosphate and nitrate cause eutrophication, degrade freshwater and lead to loss of aquatic species $[5,9]$. There is an increasing demand for the removal of phosphate and nitrate from water and wastewater, due to an increase in their pollution. High stability and solubility of nitrate and phosphate impose a great challenge for their removal [10]. Thus, the development of efficient methods and high-performance adsorbent for the removal of nitrate and phosphate is of crucial importance [9].

Physical, chemical and biological methods have been employed for nitrate and phosphate removal. Membrane separation, ion exchange, and other physical removal methods transfer or concentrate the contaminant without degrading the contaminant, leading to the formation of second contamination. The chemical reduction technique has reactivity and mobility issues and could potentially cause toxic products. Biological methods require carbon resources and a long period of microbial culturing $[11,12]$. The substantial cost of these treatments and their complexity impairs the practicality of these techniques, thus cost-effective, and highly efficient technology for nitrate and phosphate removal should be developed. Adsorption is cost-, time-, and energy efficient, does not require high operating temperature or pressure and has proven to be efficient for the elimination of nitrate and phosphate $[13,14]$. Various adsorbents for adsorption of these compounds have been applied, including fly ash, iron-based compounds, aluminum hydroxide, Ca-based adsorbents, clay, zeolite, chitosan, and carbon-based adsorbents [2, 15]. Low price, high adsorption capacity, selectivity to the pollutants and large surface area are important parameters for the adsorbent $[2,16]$.

Activated carbon has a high specific surface area, low density, microporous structure, high chemical resistance, high surface reactivity, and high adsorption capacity. It has been successfully utilized for adsorption of various chemical species $[10,14,16,17]$. Due to the high demand for activated carbon, and subsequently, the high cost of this adsorbent, utilization of renewable sources as an alternative source for the production of activated carbon has gained attention [14]. Activated carbon adsorbent has been produced from environmental waste including rice husk, grape seed, maize cob, cocoa shell, bamboo fiber, palm shell, and kenaf fiber $[14,18]$. Recently, there have been reports of Glycyrrhiza glabra as an activated carbon source for the removal of toluene from gaseous solutions. Glycyrrhiza glabra is a traditional herb with cylindrical, long, fibrous, thick, and multi-branched roots, with a high surface area. This herb has demonstrated suitable removal efficiency of $\mathrm{Pb}$ (II) and $\mathrm{Ni}(\mathrm{II})$ ions [19-21]. The utilization of agricultural waste as activated carbon precursors is renewable and less costly and could convert waste into a valuable product [22]. The physical or chemical activation method could be applied for the preparation of the activated carbon $[23,24]$. The chemical activation technique produces a higher porosity structure, involves shorter activation time and requires lower temperature [24]. Chemical activation by using $\mathrm{ZnCl}_{2}$ has been reported to produce highly porous activated carbon with high surface area [23].

Batch adsorption was carried out for the measurement of the effective adsorption of pollutants and the determination of maximum adsorption capacity [25]. The batch adsorption studies are used for the determination of mass transfer coefficients and adsorption isotherm constants. Langmuir, Freundlich and Temkin isotherms could be applied for the evaluation of the suitability of an adsorbent for nitrate and phosphate removal [26]. Activated carbon has been used in the industrial scale fixed-bed column. The continuous column provides information regarding the practicality of the adsorption process in the wastewater treatment and in industrial scale [27]. The continuous fixed-bed adsorber does not operate under equilibrium conditions, and the effect of hydrodynamic parameters (flow conditions) influences the flow behavior downstream. Dynamics of the adsorption column impose difficulties on modeling due to nonlinearities in the adsorption equilibrium isotherms and mass transfer resistance $[26,28]$. For effective design and efficient operation of a fixed-bed column, breakthrough curves developed under the operating conditions are important. The transport process in the fixed-bed column and within the adsorbent determines and influences the shape of the breakthrough curve [25]. The process parameters are important factors for the design of the adsorption system as they determine the model used for the prediction of effluent quality under the operating conditions [26].

In this study, the Glycyrrhiza glabra residues (GGR) were used for the preparation of activated carbon as a new adsorbent for nitrate and phosphate removal. To the best of authors' knowledge, this material has never been used before for the adsorption of nitrate and phosphate. The effect of carbonization temperature and the impregnation ratio of activated carbon with $\mathrm{ZnCl}_{2}$ was studied. The optimum carbonization condition was determined, and the GGR activated carbon obtained from the optimum carbonization conditions was characterized using FE-SEM, FTIR, EDX, XRD, and BET. The effect of adsorbent dosage and contact time and presence of competitor anions (bicarbonate and sulfate) was studied in the batch adsorption system. The response surface methodology (RSM) was applied to investigate the effect of parameters (initial concentration, $\mathrm{pH}$, and temperature) and their interaction on the removal efficiency. For this purpose, the central composite design (CCD) was used to predict 
the mathematical models for removal efficiencies. Furthermore, the removal efficiency of nitrate and phosphate was studied in the laboratory scale fixed-bed column. The effect of inlet concentration and volumetric flow rate on the removal efficiency of nitrate and phosphate was studied. Adams-Bohart, Thomas, and Yoon-Nelson models were applied for the analysis of the breakthrough curves. Moreover, the desorbability of the GGR activated carbon was studied for 4 desorption-adsorption cycles.

\section{Materials and methods}

\subsection{Preparation of activated carbon}

The GGR was utilized as the precursor for the preparation of activated carbon. GGR was obtained from Rishmak Company, Shiraz, Iran. Initially, the dried samples were milled and were soaked in distilled water for $24 \mathrm{~h}$. The sample was subsequently washed several times with distilled water. The samples were dried in the oven at $110^{\circ} \mathrm{C}$ for the duration of $24 \mathrm{~h}$. The sieve shaker was utilized for the separation of a fraction of the sample within the diameter range of $0.3-1 \mathrm{~mm}$. Chemical activation of GGR granules was carried out using $\mathrm{ZnCl}_{2}\left(1.467 \mathrm{~mol} \mathrm{~L}^{-1}\right)$. Initially, the dried GGR was mixed with different ratios (1:1, 1:1.5, 1:2) of $\mathrm{ZnCl}_{2}$ and was subsequently allowed to soak for $24 \mathrm{~h}$ at room temperature. The $\mathrm{GGR}$ impregnated with $\mathrm{ZnCl}_{2}$ was dried in the oven for $24 \mathrm{~h}$ at $110^{\circ} \mathrm{C}$. In the second step, the sample was carbonized in the furnace at the desired temperatures $\left(450,650\right.$ and $\left.850^{\circ} \mathrm{C}\right)$ under the nitrogen flow rate of $200 \mathrm{~mL} \mathrm{~min}^{-1}$. The heating rate of the carbonization process was $10^{\circ} \mathrm{C} \mathrm{min}{ }^{-1}$ from the ambient temperature to the desired temperature, and the sample was held at the final temperature for the duration of $1 \mathrm{~h}$. The resultant activated carbon soaked in $2 \mathrm{M} \mathrm{HCl}$ for $2 \mathrm{~h}$ for the removal of residual zinc. Hot distilled water was used for washing the prepared activated carbon. The activated carbon was dried in the oven at $110^{\circ} \mathrm{C}$ for $24 \mathrm{~h}$ and was subsequently stored in glass bottles. GGR activated carbon prepared at different conditions (temperature and impregnation ratio) was used for the evaluation of nitrate removal. For this purpose, the batch system was utilized to remove nitrate from the aqueous solution of nitrate. An amount of $1 \mathrm{~g}$ of prepared GGR activated carbon was added to $100 \mathrm{~mL}$ of $100 \mathrm{mg} \mathrm{L}^{-1}$ aqueous nitrate solution at a pH of 7 and a temperature of $25^{\circ} \mathrm{C}$ for $180 \mathrm{~min}$. The optimum activation conditions were achieved, and the characterization tests were conducted on the optimum prepared GGR activated carbon.

\subsection{Characterization of the prepared adsorbents}

Field emission scanning electron micrographs (Mira3 model, Tescan, Czech) were utilized to study the surface morphology of the adsorbent prepared at the optimum activation conditions. The adsorbent was coated with gold for charge dissipation during the FE-SEM imaging. The chemical structure of carbon and the functional group of the adsorbent were determined from the Fourier transform infrared spectrometer (6300 Jasco, Japan). FTIR spectra were measured from 400 to $4000 \mathrm{~cm}^{-1}$ at the resolution of $4 \mathrm{~cm}^{-1}$ [29]. The chemical analysis of the adsorbent was determined from the energy-dispersive X-ray (EDX) instrument [30]. X-ray diffraction (XRD) (D8 Advance, Bruker, Germany) patterns were collected by using $\mathrm{Cu} K_{\alpha}$ radiation $\left(\lambda=1.5405^{\circ} \mathrm{A}\right)$ in the $2 \theta$ range of $5^{\circ}-80^{\circ}$. The surface area and pore distribution of the activated carbon were obtained through the surface area and pore size analyzer (BELSORP-mini II, Japan). The specific surface area of the adsorbent was determined from the Brunauer-Emmett-Teller (BET) method using $\mathrm{N}_{2}$ adsorption data at $77 \mathrm{~K}$. The density functional theory was used for the estimation of pore size distribution.

\subsection{Batch adsorption}

Adsorption of nitrate and phosphate from aqueous solution (100 $\left.\mathrm{mg} \mathrm{L}^{-1}\right)$ was carried out by using different adsorbent dosage $(0.1-1 \mathrm{~g}$ in $100 \mathrm{~mL})$ at $25^{\circ} \mathrm{C}$ and $\mathrm{pH}$ of 7 for $180 \mathrm{~min}$ shaking period at $100 \mathrm{rpm}$. Batch nitrate and phosphate adsorption experiments were conducted by adding the optimum amount of GGR activated carbon to each of the aqueous solutions of nitrate and phosphate within the different range of initial concentrations. The $0.1 \mathrm{M} \mathrm{H}_{2} \mathrm{SO}_{4}$ or $\mathrm{NaOH}$ solution was used to adjust the $\mathrm{pH}$. Samples were agitated in the shaking incubator (NB-205V, Techno-park) at $100 \mathrm{rpm}$ to control the temperature of the samples. Subsequently, the concentration of nitrate and phosphate in the solutions was determined by a UV-Vis spectrophotometer (DR-5000 Hach, USA) at $220 \mathrm{~nm}$ for nitrate and $430 \mathrm{~nm}$ for phosphate. The nitrate and phosphate adsorbed on the adsorbent were calculated according to Eq. 1. In Eq. 1, $q_{\mathrm{e}}\left(\mathrm{mg} \mathrm{g}^{-1}\right)$ is the equilibrium amount of adsorbate on the adsorbent, $C_{0}$ and $C_{e}$ represent the initial and equilibrium concentration of adsorbate $\left(\mathrm{mg} \mathrm{L}^{-1}\right)$, $v$ is the solution volume (L), and $m$ is the dosage of the adsorbent $(\mathrm{g})$ in the mixture. The removal efficiency of the nitrate and phosphate $(R \%)$ in the solution was determined from Eq. 2 [7].

$q_{\mathrm{e}}=v\left(C_{0}-C_{\mathrm{e}}\right) / m$ 
$R \%=100\left(C_{0}-C_{\mathrm{e}}\right) / C_{0}$

\subsubsection{Kinetic studies}

The rate of adsorption of nitrate and phosphate on the activated GGR was studied at different time periods. In the kinetic studies for nitrate and phosphate adsorption, the specific amount of GGR activated carbon was, respectively, added to each of $100 \mathrm{~mL}$ of $50 \mathrm{mg} \mathrm{L}^{-1}$ nitrate solution $\mathrm{pH}$ of 2 and $100 \mathrm{~mL}$ of $40 \mathrm{mg} \mathrm{mL}^{-1}$ phosphate solution $\mathrm{pH}$ of 4 . The mixtures were agitated in the shaking incubator at $100 \mathrm{rpm}$ and different temperatures $\left(25,35\right.$, and $\left.45^{\circ} \mathrm{C}\right)$ until adsorption equilibrium was achieved. The effect of $\mathrm{HCO}_{3}^{-}$and $\mathrm{SO}_{4}^{2-}$ anion on the adsorption kinetics of nitrate and phosphate was studied separately. For this purpose, $10 \mathrm{mg}$ of $\mathrm{KHCO}_{3}$ and $5 \mathrm{mg}$ of $\mathrm{K}_{2} \mathrm{SO}_{4}$ were added to $100 \mathrm{~mL}$ of $50 \mathrm{mg} \mathrm{L}^{-1}$ nitrate solution and $40 \mathrm{mg} \mathrm{L}^{-1}$ phosphate solution [6].

\subsubsection{Response surface methodology}

To determine the effect of the studied parameters (A: initial concentration, $\mathrm{B}: \mathrm{pH}, \mathrm{C}$ : temperature) and their interaction on the removal efficiency of nitrate and phosphate, the central composite design (CCD) was used. Furthermore, CCD was applied for obtaining prediction models for the removal efficiencies. For the CCD, three levels $(\alpha=1)$ and three parameters were used, to determine the number and the conditions of the experiment to be carried out. Table 1 demonstrates the factors and levels of nitrate and phosphate adsorption. The $\mathrm{pH}$ range for phosphate was considered from $\mathrm{pH} 4$, since phosphate exists as $\mathrm{H}_{3} \mathrm{PO}_{4}$, $\mathrm{H}_{2} \mathrm{PO}_{4}^{-}, \mathrm{HPO}_{4}^{2-}$, and $\mathrm{PO}_{4}^{3-}$ at different $\mathrm{pH}$. At acidic $\mathrm{pH}$, the phosphate exists as $\mathrm{H}_{3} \mathrm{PO}_{4}$ which adsorbs weakly to the adsorption sites. Thus, the experiments were conducted in the $\mathrm{pH}$ range of 4-10 [31, 32].

\subsection{Fixed-bed adsorption}

Fixed-bed column adsorption studies were carried out for evaluation of the feasibility of the adsorbent in the continuous system in the $21 \mathrm{~mm}$ diameter and $300 \mathrm{~mm}$ height column. The column was packed with GGR activated carbon to the height of $10 \mathrm{~cm}$. The feed was introduced from the bottom of the column, to prevent the channeling effect. To study the effect of volumetric flow rate on the nitrate and phosphate removal, the peristaltic pump (DLX$M A / A D$, ETATRON D.S.) was used for pumping the feed at the different rates of 10,25 , and $40 \mathrm{~mL} \mathrm{~min}^{-1}$ from the solution containing nitrate $(\mathrm{pH}=2)$ and phosphate $(\mathrm{pH}=4)$ which had the concentration of $50 \mathrm{mg} \mathrm{L}^{-1}$ and $40 \mathrm{mg} \mathrm{L}^{-1}$, respectively (temperature of $25^{\circ} \mathrm{C}$ ). For evaluation of the impact of inlet feed concentration on nitrate and phosphate removal, the experiments were conducted with a fixed volumetric flow rate of $40 \mathrm{~mL} \mathrm{~min}^{-1}$ at different concentrations of 20,60 and $100 \mathrm{mg} \mathrm{L}^{-1}$ for nitrate and phosphate. The effluent solutions were collected at regular time intervals and the nitrate and phosphate concentrations were tested. The breakthrough curve is determined from the experimental data of $\frac{C_{t}}{C_{0}}$ versus time $\left(C_{t}\right.$ is the concentration in the outlet at a given time, and $C_{0}$ is the inlet concentration). The length of the unused bed (LUB) was determined from Eq. 3 , in which $t_{\mathrm{b}}$ (breakthrough time: the time at which the maximum allowable concentration of nitrate and phosphate is reached) was obtained from Eq. 4 and $t^{5}$ (the time equivalent for a total capacity of the adsorption bed) was obtained from Eq. 5 [33, 34].

$\mathrm{LUB}=L\left(1-\frac{t_{\mathrm{b}}}{t^{\mathrm{s}}}\right)$

$t_{\mathrm{b}}=\int_{0}^{t_{\mathrm{b}}}\left(1-\frac{c_{t}}{c_{0}}\right) \mathrm{d} t$

$t^{\mathrm{s}}=\int_{0}^{t_{\mathrm{f}}}\left(1-\frac{c_{t}}{c_{0}}\right) \mathrm{d} t$

\subsection{Desorption studies}

To determine the reusing ability of the GGR activated adsorbent, it is important to investigate desorption of
Table 1 (a) Process variables and levels for nitrate adsorption, (b) process variables and levels for phosphate adsorption

\begin{tabular}{|c|c|c|c|c|c|c|c|}
\hline \multicolumn{4}{|l|}{$a$} & \multicolumn{4}{|l|}{$b$} \\
\hline \multirow[t]{2}{*}{ Factors } & \multicolumn{3}{|c|}{ Levels } & \multirow[t]{2}{*}{ Factors } & \multicolumn{3}{|c|}{ Levels } \\
\hline & -1 & 0 & +1 & & -1 & 0 & +1 \\
\hline $\begin{array}{l}\text { A: initial concentration } \\
\left(\mathrm{mg} \mathrm{L}^{-1}\right)\end{array}$ & 20 & 60 & 100 & $\begin{array}{l}\text { A: initial concentration } \\
\quad\left(\mathrm{mg} \mathrm{L}^{-1}\right)\end{array}$ & 20 & 60 & 100 \\
\hline $\mathrm{B}: \mathrm{pH}$ & 2 & 6 & 10 & $\mathrm{~B}: \mathrm{pH}$ & 4 & 7 & 10 \\
\hline $\mathrm{C}:$ temperature $\left({ }^{\circ} \mathrm{C}\right)$ & 25 & 35 & 45 & $\mathrm{C}:$ temperature $\left({ }^{\circ} \mathrm{C}\right)$ & 25 & 35 & 45 \\
\hline
\end{tabular}


nitrate and phosphate from the GGR activated carbon. For this purpose, in the batch adsorption system, the adsorbent that was utilized for the adsorption of nitrate $\left(C_{0}=50 \mathrm{mg} \mathrm{L}^{-1}, \mathrm{pH}=2\right.$, and $T=25^{\circ} \mathrm{C}$ ) and phosphate $\left(C_{0}=40 \mathrm{mg} \mathrm{L}^{-1}, \mathrm{pH}=4\right.$, and $T=25^{\circ} \mathrm{C}$ ) was centrifuged. Desorption of the nitrate and phosphate from the GGR activated carbon was conducted by immersing the adsorbent in $100 \mathrm{~mL}$ of $0.1 \mathrm{M} \mathrm{NaOH}$ for $90 \mathrm{~min}$ and $120 \mathrm{~min}$ for nitrate and phosphate adsorbents, respectively. The used adsorbent was subjected to the desorption-adsorption process for 5 times, and the removal efficiency of each stage was obtained for nitrate and phosphate.

Desorption studies for the fixed-bed column were performed by initially pumping the distilled water at $40 \mathrm{~mL} \mathrm{~min}-1$ for $5 \mathrm{~min}$. Subsequently, an amount of $10 \mathrm{~mL} \mathrm{~min}-1$ of $0.1 \mathrm{M} \mathrm{NaOH}$ solution was pumped in the fixed-bed column for $150 \mathrm{~min}$ and $180 \mathrm{~min}$ for nitrate and phosphate, respectively, at the temperature of $25^{\circ} \mathrm{C}$. The used adsorbent was reused in 4 cycles of desorption-adsorption $\left(C_{0}=50 \mathrm{mg} \mathrm{L}^{-1}\right.$ for nitrate and $C_{0}=40 \mathrm{mg} \mathrm{L}^{-1}$ for phosphate, $Q=40 \mathrm{~mL} \mathrm{~min}^{-1}$ ), and the breakthrough curves were obtained for each adsorption stage of each cycle [6].

\subsection{Adsorption models}

The adsorption data obtained from the batch and fixedbed system were analyzed using the adsorption models stated in Table 2. In this study, the pseudo-first-order, pseudo-second-order, and intra-particle diffusion models were studied. The Adams-Bohart, Thomas, and Yoon-Nelson models were used to describe the behavior of the fixed-bed column. The initial part of the breakthrough curved was described by the Adams-Bohart model. The Thomas model is applied for adsorption systems that possess no internal and external diffusions by assuming plug flow behavior [6]. The application of the Yoon-Nelson model for nitrate and phosphate removal considers that the reduction in the probability of adsorption of nitrate and phosphate is proportional to the probability of nitrate and phosphate adsorption and the breakthrough of nitrate and phosphate on the adsorbent [6]. The adsorption isotherms state the equilibrium amount of nitrate and phosphate in the adsorbent and the aqueous phase [20]. Langmuir isotherm considers a monolayer adsorption onto the finite adsorption surface sites and assumes independent adsorption enthalpy from the adsorbed amount of adsorbate. Freundlich isotherm assumes that by increasing the adsorption occupied sites the enthalpy of adsorption of a heterogeneous surface decreases logarithmically [35]. Temkin isotherm considers the interaction effect between adsorbate and adsorbent. Furthermore, this model considers that the enthalpy of adsorption in the adsorption layer reduces linearly by increasing the adsorption occupied sites [36]. The constants of each model are determined

Table 2 Batch equilibrium adsorption models, batch kinetic models, and column kinetic models [6, 9, 36, 40]

\begin{tabular}{|c|c|c|c|c|c|}
\hline Experiments & Models & Equation & Linearized form & Parameters & Equations no. \\
\hline \multirow{3}{*}{$\begin{array}{l}\text { Batch kinetic } \\
\text { models }\end{array}$} & Pseudo-first order & $\frac{\mathrm{d} q_{\mathrm{t}}}{\mathrm{d} t}=k_{1}\left(q_{\mathrm{e}}-q_{t}\right)$ & $\ln \left(q_{\mathrm{e}}-q_{\mathrm{t}}\right)=\ln \left(q_{\mathrm{e}}\right)-k_{1} t$ & $k_{1}, q_{\mathrm{e}}$ & (6) \\
\hline & Pseudo-second order & $\frac{\mathrm{d} q_{\mathrm{t}}}{\mathrm{d} t}=k_{2}\left(q_{\mathrm{e}}-q_{t}\right)^{2}$ & $\frac{t}{q_{t}}=\frac{1}{k_{2} q_{\mathrm{e}}^{2}}+\frac{t}{q_{\mathrm{e}}}$ & $k_{2}, q_{\mathrm{e}}$ & (7) \\
\hline & Interparticle diffusion & $\frac{\mathrm{d} q_{\mathrm{t}}}{\mathrm{d} t}=k_{\mathrm{int}} t^{-0.5} / 2$ & $q_{t}=k_{\mathrm{int}} t^{0.5}+C$ & $k_{\mathrm{int}}, C$ & (8) \\
\hline \multirow[t]{3}{*}{ Batch equilibrium } & Langmuir & $q_{\mathrm{e}}=\frac{q_{m} K_{\mathrm{L}} C_{\mathrm{e}}}{1+K_{\mathrm{L}} C_{\mathrm{e}}}$ & $\frac{c_{\mathrm{e}}}{q_{\mathrm{e}}}=\frac{1}{K_{\mathrm{L}} q_{m}}+\frac{c_{\mathrm{e}}}{q_{m}}$ & $q_{m}, K_{\mathrm{L}}$ & (9) \\
\hline & Freundlich & $q_{\mathrm{e}}=K_{\mathrm{F}} c_{\mathrm{e}}^{\frac{1}{n}}$ & $\ln \left(q_{\mathrm{e}}\right)=\ln K_{\mathrm{F}}+\frac{\ln c_{\mathrm{e}}}{n}$ & $K_{\mathrm{F}}, n$ & (10) \\
\hline & Temkin & $q_{\mathrm{e}}=B_{\mathrm{T}} \ln \left(K_{\mathrm{T}} C_{\mathrm{e}}\right)$ & $q_{\mathrm{e}}=B_{\mathrm{T}} \ln \left(K_{\mathrm{T}}\right)+B_{\mathrm{T}} \ln \left(c_{\mathrm{e}}\right)$ & $K_{\mathrm{T}}, B_{\mathrm{T}}$ & $(11)$ \\
\hline \multirow[t]{3}{*}{$\begin{array}{l}\text { Column kinetic } \\
\text { models }\end{array}$} & Adams-Bohart & $\frac{c_{t}}{c_{0}}=\exp \left(K_{A B} c_{0} t-K_{A B} N_{0} \frac{z}{U_{0}}\right)$ & $\ln \left(\frac{c_{t}}{c_{0}}\right)=K_{A B} c_{0} t-K_{A B} N_{0} \frac{z}{U_{0}}$ & $K_{A B}, N_{0}$ & $(12)$ \\
\hline & Thomas & $\frac{c_{t}}{c_{0}}=\left[\exp \left(\frac{K_{\mathrm{Th}} m q_{0}}{Q}-K_{\mathrm{Th}} c_{0} t\right)+1\right]^{-1}$ & $\ln \left(\frac{c_{0}}{c_{t}}-1\right)=\frac{K_{\mathrm{Th}} m q_{0}}{Q}-K_{\mathrm{Th}} c_{0} t$ & $K_{\mathrm{Th}}, m q_{0}$ & (13) \\
\hline & Yoon and Nelson & $\frac{c_{t}}{c_{0}}=\left[\exp \left(K_{Y N} \tau-K_{Y N} t\right)+1\right]^{-1}$ & $\ln \left(\frac{c_{t}-c_{0}}{c_{0}}\right)=K_{Y N} t-K_{Y N} \tau$ & $K_{Y N}, \tau$ & (14) \\
\hline
\end{tabular}

$C_{\mathrm{e}}=$ equilibrium concentration $\left(\mathrm{mg} \mathrm{L}^{-1}\right), q_{\mathrm{e}}=$ amount of adsorbate per unit mass of adsorbent $\left(\mathrm{mg} \mathrm{g}^{-1}\right), q_{\mathrm{m}}=$ maximum amount of adsorbate $\left(\mathrm{mg} \mathrm{g}^{-1}\right), K_{\mathrm{L}}=$ Langmuir constant $\left(\mathrm{L} \mathrm{mg}^{-1}\right), K_{\mathrm{F}}=$ Freundlich constant $\left(\mathrm{mg} \mathrm{g}^{-1}\right)\left(\mathrm{L} \mathrm{mg}^{-1}\right)^{1 / n}, n=$ Freundlich constant, $K_{\mathrm{T}}=$ Temkin constant $\left(\mathrm{L} \mathrm{mg}^{-1}\right), B_{\mathrm{T}}=R T / b_{\mathrm{T}}\left(b_{\mathrm{T}}\right.$ constant related to heat of sorption $\left.\mathrm{kJ} \mathrm{mol}^{-1}\right), q_{t}=$ amount of adsorbate at time $\left(\mathrm{mg} \mathrm{g}^{-1}\right), K_{1}=$ rate constant of pseudo-first order $\left(\mathrm{min}^{-1}\right), K_{2}=$ rate constant of pseudo-second order $\left(\mathrm{g} \mathrm{mg}^{-1} \mathrm{~min}^{-1}\right), K_{\text {int }}=$ intra-particle diffusion constant ( $\mathrm{mg} \mathrm{g}^{-1} \mathrm{~min}^{-05}$, the parameter $C$ should be 0 if the intra-particle diffusion is the rate-controlling step. $K_{A B}=$ kinetic constant $\left(\mathrm{L} \mathrm{mg}^{-1} \mathrm{~min}^{-1}\right), U_{0}=$ linear velocity (volumetric flow rate/column section area, $\left.\mathrm{cm} \mathrm{min}^{-1}\right), Z=$ bed length of the column $(\mathrm{cm}), N_{0}=$ saturation concentration $\left(\mathrm{mg} \mathrm{L}^{-1}\right), K_{\mathrm{Th}}=$ Thomas rate constant $\left(\mathrm{mL} \mathrm{min}^{-1} \mathrm{mg}^{-1}\right), m q_{0}=$ mass of adsorbate at the equilibrium $(\mathrm{mg}), C_{0}=$ inlet concentration $\left(\mathrm{mg} \mathrm{L}^{-1}\right), C_{t}=$ outlet concentration at time $t\left(\mathrm{mg} \mathrm{L}^{-1}\right), Q=$ volumetric flow rate $\left(\mathrm{mL} \mathrm{min}^{-1}\right), t=$ time $(\mathrm{min}), \tau=$ time required for $50 \%$ adsorbate breakthrough (min), $K_{Y N}=$ rate constant $\left(\mathrm{min}^{-1}\right)$ 
from the linearized form of that model, as indicated in Table 2.

\section{Results and discussion}

\subsection{Optimum preparation conditions of the GGR activated carbon}

To prepare the GGR activated carbon with the highest nitrate removal potential, the GGR impregnation ratio ( $m_{\mathrm{p}}: m_{\mathrm{ZnCl}_{2}}, m_{\mathrm{p}}$ is the mass of dried GGR, and $m_{\mathrm{ZnCl}_{2}}$ is the mass of $\mathrm{ZnCl}_{2}$ ), and carbonization temperature was varied between $1: 1,1: 1.5,1: 2$, and 450,650 , and $850^{\circ} \mathrm{C}$, respectively. Table 3 demonstrates the nitrate removal efficiency obtained at different preparation conditions of the GGR activated carbon. The CCD was applied for the determination of the impact of the studied parameters on the

Table 3 Nitrate removal efficiency obtained from activated carbon prepared at different temperatures and ratios of the weight of the dried plant to $\mathrm{ZnCl}_{2}$

\begin{tabular}{llll}
\hline No. & $\begin{array}{l}\text { Carbonization tempera- } \\
\text { ture }\left({ }^{\circ} \mathrm{C}\right)\end{array}$ & $m_{\mathrm{p}}: m_{\mathrm{ZnCl}_{2}}$ & $R_{N} \%$ \\
\hline 1 & 450 & $1: 1$ & 59.68 \\
2 & 650 & $1: 1$ & 61.36 \\
3 & 450 & $1: 2$ & 67.16 \\
4 & 850 & $1: 2$ & 79.12 \\
5 & 850 & $1: 1$ & 65.78 \\
6 & 450 & $1: 1.5$ & 65.36 \\
7 & 650 & $1: 2$ & 73.14 \\
8 & 850 & $1: 1.5$ & 76.12 \\
9 & 650 & $1: 1.5$ & 72.65 \\
\hline
\end{tabular}

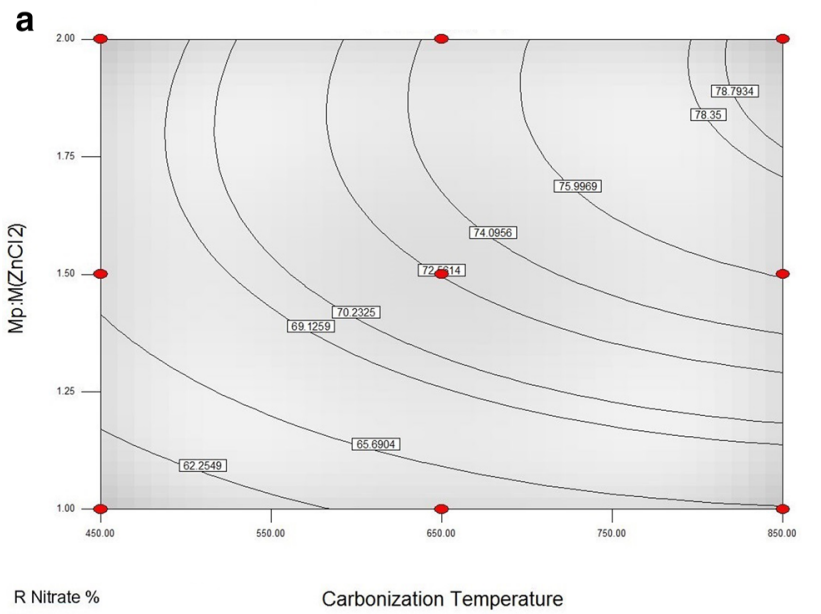

nitrate removal. Figure 1 demonstrates the effect of studied parameters on nitrate removal. According to Table 3 and Fig. 1, by increasing the carbonization temperature and impregnation ratio, the efficiency of the prepared GGR activated carbon was increased. At impregnation ratio of $1: 2$ and temperature of $850^{\circ} \mathrm{C}$, the nitrate removal efficiency was $79.12 \%$. At higher carbonization temperatures, more volatile compounds were released, and thus a porous structure was formed. Therefore, the removal efficiency of nitrate increased. Similar trends were observed in other research studies $[10,11]$. Phenol groups present in the activated carbon have acidic properties. The $\mathrm{H}$ from Phenol reacts with $\mathrm{Cl}$ of $\mathrm{ZnCl}_{2}$. Therefore the oxygen of phenol that has lost its $\mathrm{H}$ would enter the pair electrons into the empty orbital of $\mathrm{Zn}$. $\mathrm{Zn}$ has two $\mathrm{Cl}$ and thus can react with two structures that have phenol groups and can form cross-link [41]. The $\mathrm{ZnCl}_{2}$ develops cross-links, resulting in the creation of a rigid matrix; therefore, the nitrate removal would increase by increasing the $\mathrm{ZnCl}_{2}$ ratio [42] .

\subsection{Characterization of GGR activated carbon}

Figure 2 demonstrates the FE-SEM of the prepared GGR activated carbon. This figure demonstrates the irregular and porous morphology of the adsorbent that has occurred due to the removal of volatile compounds and impurities during the activation process with $\mathrm{ZnCl}_{2}$. The activated carbon acquired at the temperature of $850^{\circ} \mathrm{C}$ and the impregnation ratio of 1:2 had a porous surface, indicating a high surface area. The FTIR spectra of the GGR activated carbon are demonstrated in Fig. 3a. The displayed bands at $661.184 \mathrm{~cm}^{-1}$ and $673.035 \mathrm{~cm}^{-1}$ represent the $\mathrm{C}-\mathrm{Cl}$ bonding. The peak at $1115.62 \mathrm{~cm}^{-1}$ is assigned to the $\mathrm{S}-\mathrm{O}$ linkage or $\mathrm{C}-\mathrm{O}$ stretching linkage

b

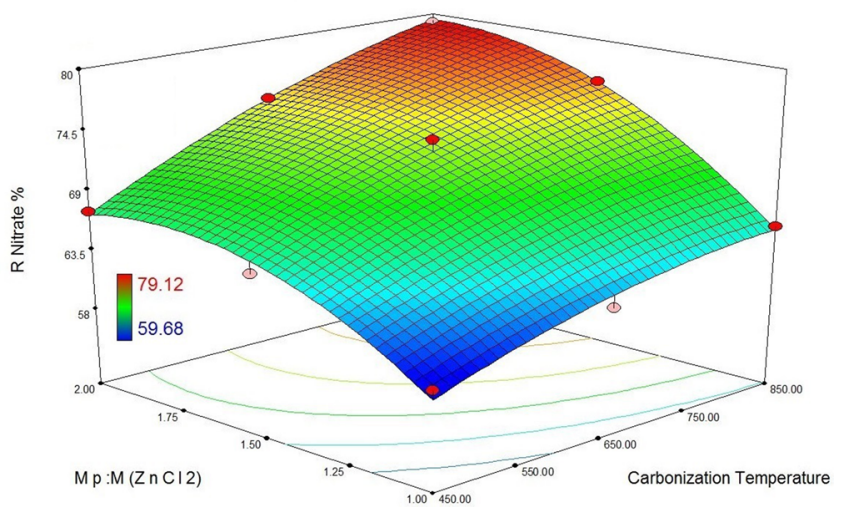

Fig. 1 a Contour plot and $\mathbf{b}$ response surface plot showing the effects of carbonization temperature and impregnation ratio on the nitrate removal 

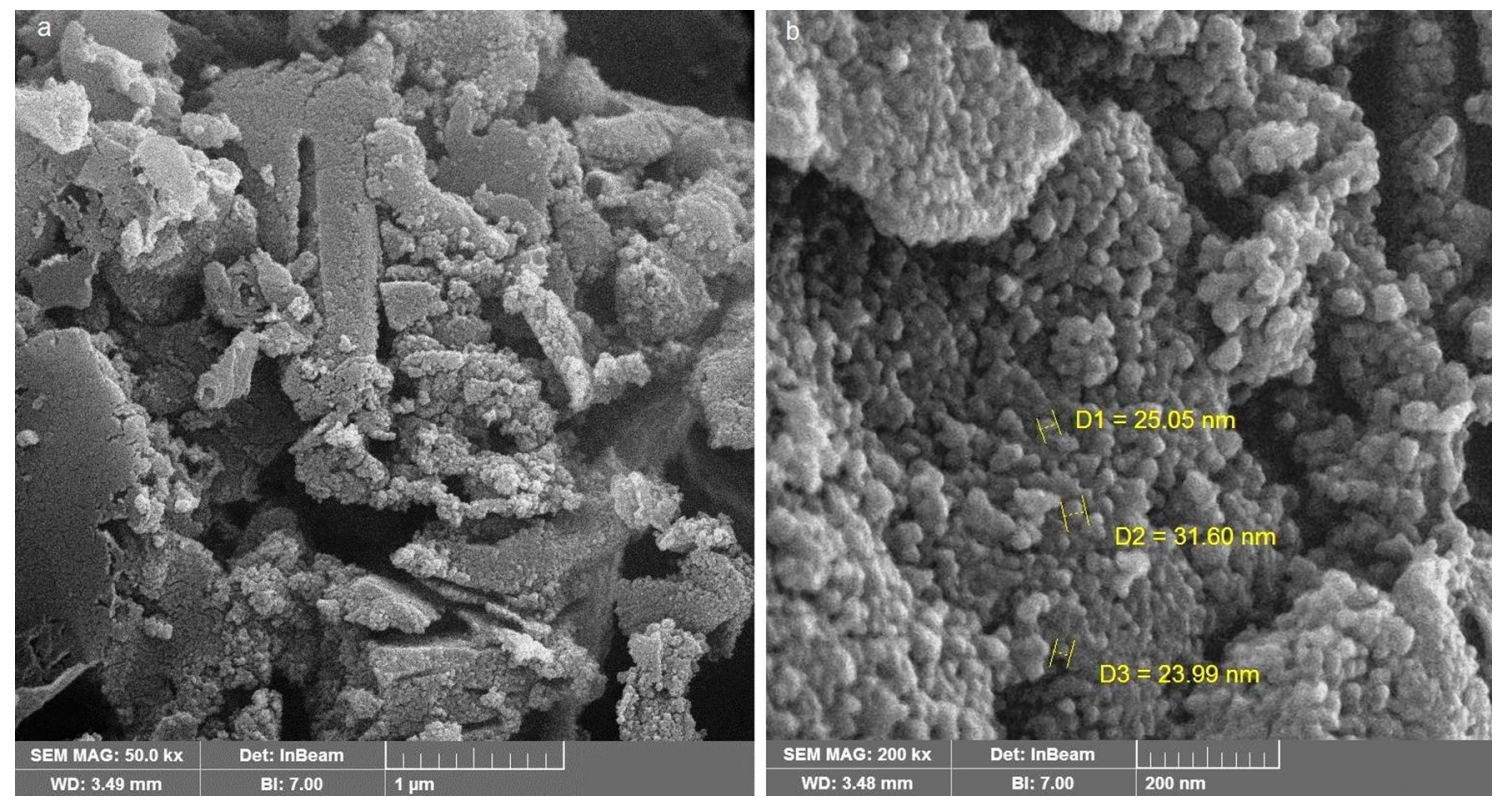

Fig. 2 a FE-SEM of GGR activated carbon at $1 \mu \mathrm{m}$, b FE-SEM of GGR activated carbon at $200 \mathrm{~nm}$

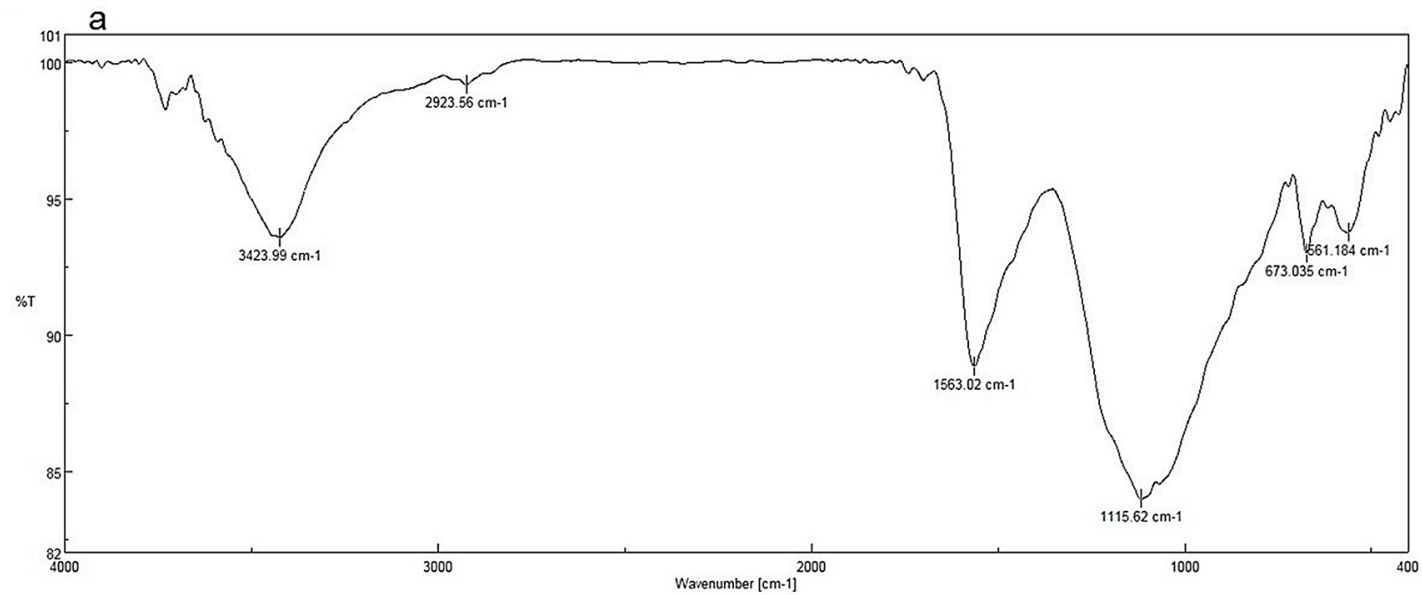

b
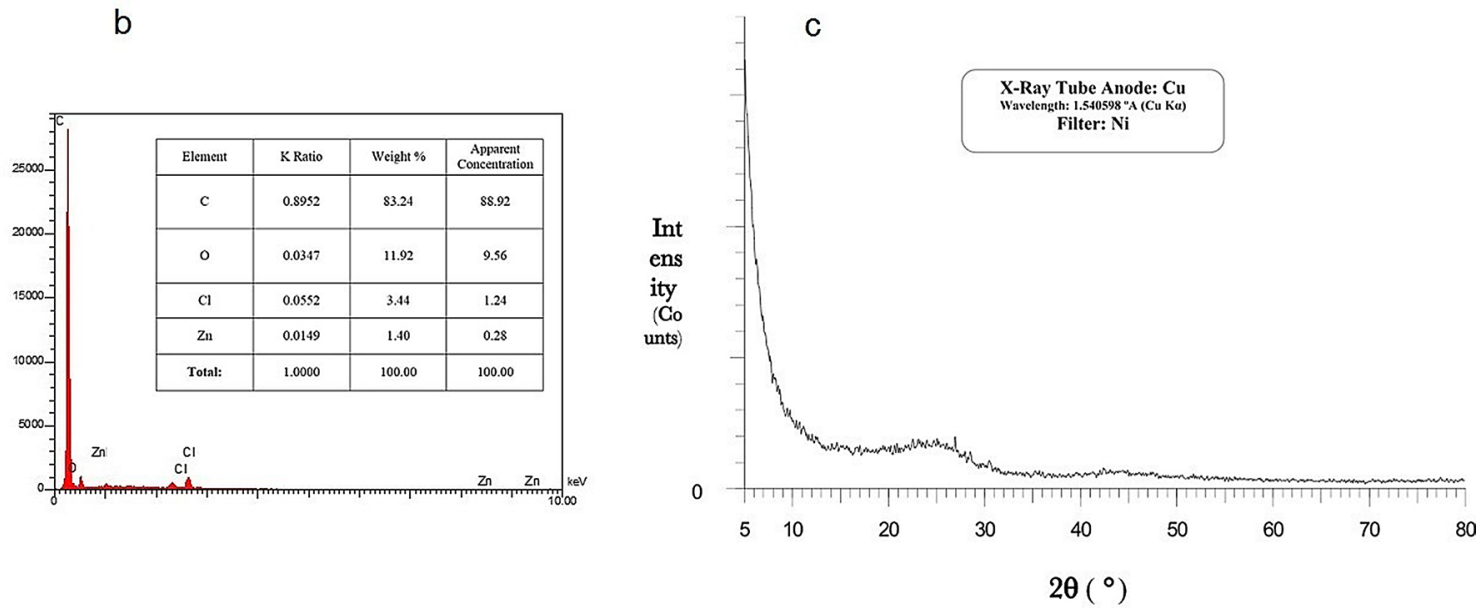

Fig. 3 a FTIR spectra of GGR activated carbon, b EDX spectra of GGR activated carbon, c XRD spectra of GGR activated carbon 
from alcohols, ethers or hydroxyl groups. The band at $1563.02 \mathrm{~cm}^{-1}$ is indicative of $\mathrm{C}=\mathrm{C}$ linkage. The peak at $2923.56 \mathrm{~cm}^{-1}$ is attributed to the $\mathrm{C}-\mathrm{H}$ bonding of methyl and methylene groups. The peak at $3423.99 \mathrm{~cm}^{-1}$ represents the $\mathrm{O}-\mathrm{H}$ bonding of hydroxyl, carboxyl group, and phenol or alcohol groups. The loading capacity of activated carbon is not determined from the pore structure alone, and the chemical nature of the surface of adsorbent is also important. Heteroatoms (oxygen, hydrogen, nitrogen) are present in the structure of activated carbon as single atoms or functional groups. Oxygen is the heteroatom present most in the matrix of activated carbon. The combination of oxygen-carbon in activated carbon has the highest impact on reactions and surface behavior of activated carbon [29]. The surface of activated carbon contains functional groups with oxygen sites and amino sites. Figure $3 \mathrm{~b}$ depicts the EDX spectra with the elemental analysis of the GGR activated carbon. The table inset in the EDX spectra indicates the quantitative elemental analysis in weight $\%$ for the adsorbent, which was determined to have $83.24 \%$ carbon, $11.92 \%$ oxygen, $3.44 \% \mathrm{Cl}$, and $1.40 \%$ $\mathrm{Zn}$. From the EDX spectra, it is evident that the highest component present is carbon; furthermore, $\mathrm{Zn}$ and $\mathrm{Cl}$ are present due to the utilization of $\mathrm{ZnCl}_{2}$ as the precursor. The presence of $\mathrm{Zn}$ and $\mathrm{Cl}$ on the surface of adsorbent could

Table 4 Results of BET analysis

\begin{tabular}{llll}
\hline $\begin{array}{l}\text { Surface area } \\
\left(\mathrm{m}^{2} \mathrm{~g}^{-1}\right)\end{array}$ & $\begin{array}{l}\text { Total pore volume } \\
\left(\mathrm{cm}^{3} \mathrm{~g}^{-1}\right)\end{array}$ & $\begin{array}{l}\text { Mean diameters } \\
\text { of pores }(\mathrm{nm})\end{array}$ & Yield \% \\
\hline 959.22 & 0.5431 & 2.2227 & 40 \\
\hline
\end{tabular}

block the active sites and hinder the adsorption of nitrate and phosphate [30].

The X-ray diffraction profile of GGR activated carbon is shown in Fig. 3c. The lack of an exhibition of well-defined peaks in the XRD spectra indicates that the discrete mineral phase was not detected. Thus, the GGR activated carbon has an amorphous structure. The hump at $2 \theta$ of $25^{\circ}$ indicates the high degree of disorder of the produced carbonaceous material.

Table 4 demonstrates the results of the BET analysis. The specific surface area was determined to be $959.22 \mathrm{~m}^{2} \mathrm{~g}^{-1}$. The yield (mass of GGR activated carbon/mass of dried GGR) of GGR activated carbon was $40 \%$.

\subsection{Batch adsorption studies}

\subsubsection{Adsorbent dosage studies}

To determine the effect of adsorbent dosage on the removal efficiency of nitrate and phosphate, the adsorbent dose was varied between 0.1 and $1 \mathrm{~g}$ in $100 \mathrm{~mL}$ aqueous solution (100 $\mathrm{mg} \mathrm{L}^{-1}$ ). According to Fig. 4 , the removal efficiency of nitrate and phosphate increased with increasing the amount of adsorbent, due to an increased surface area. When the adsorbent amount increased from 1 to $4 \mathrm{~g} \mathrm{~L}^{-1}$, the nitrate adsorption increased from 55.12 to $75.35 \%$. Similarly, an increase in the adsorbent amount from 1 to $6 \mathrm{~g} \mathrm{~L}^{-1}$ increased the removal efficiency of phosphate from 41.56 to $76.09 \%$. Furthermore, the adsorbent affinity toward adsorbing nitrate was higher than phosphate at low adsorbent dosage. At high adsorbent dosage, the equilibrium uptake of nitrate and phosphate did not increase considerably, due to the conglomeration of
Fig. 4 Effect of adsorbent dosage on nitrate and phosphate removal efficiency

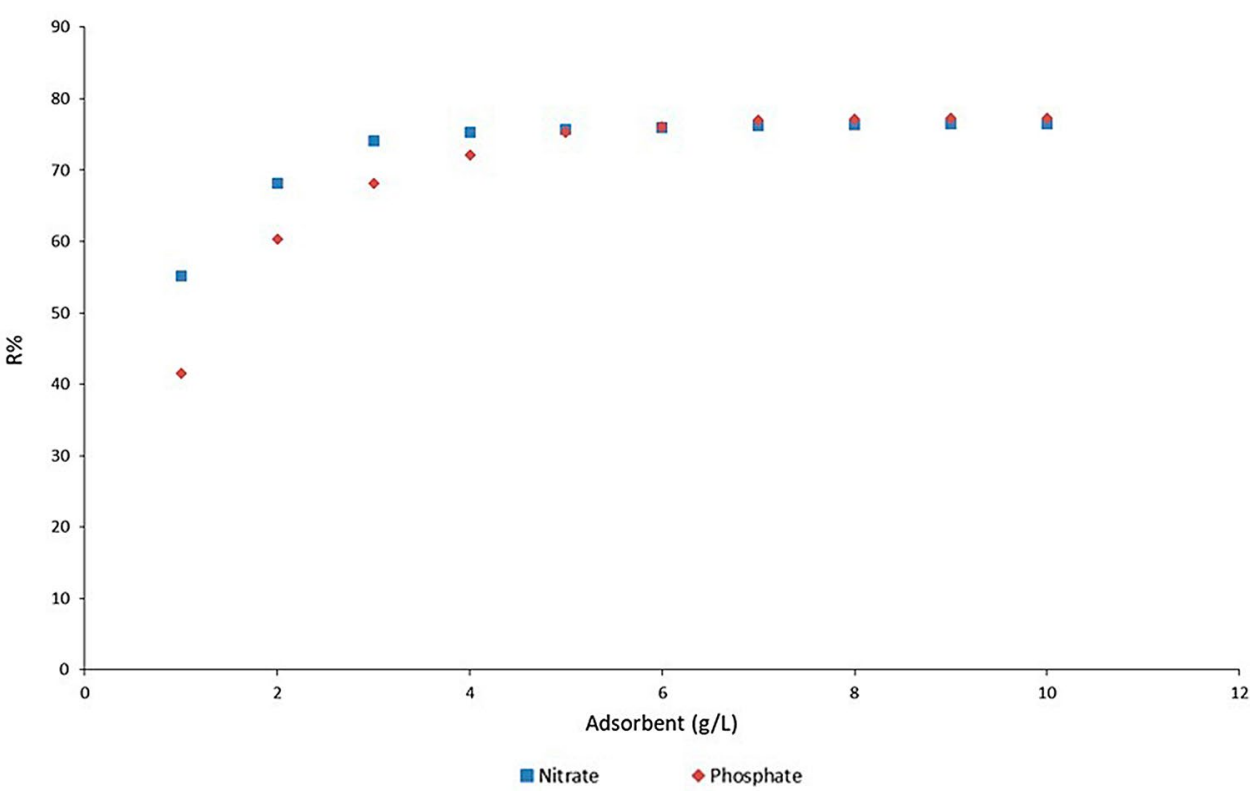


adsorbent particles [35]. Therefore, the optimum GGR activated carbon dosage for nitrate and phosphate removal was $4 \mathrm{~g} \mathrm{~L}^{-1}$ and $6 \mathrm{~g} \mathrm{~L}^{-1}$, respectively.

\subsubsection{Adsorption kinetics}

Figure 5 displays the adsorption kinetics of nitrate and phosphate separately and in the presence of competitive anions. These data were obtained at the temperatures of 25,35 , and $45^{\circ} \mathrm{C}$. According to Fig. $5 \mathrm{a}$, b, the equilibrium time for nitrate removal was $90 \mathrm{~min}$, while the equilibrium time for nitrate in the presence of competitor anions was prolonged to $150 \mathrm{~min}$, and the adsorption capacity was decreased. This occurrence has resulted from the occupation of the adsorption sites with the competitor anions [7]. The adsorption kinetic study of phosphate (Fig. 5b, c) indicates that the equilibrium time for phosphate removal and phosphate removal in the presence of competitor anions was $120 \mathrm{~min}$. According to Table 5, the pseudo-first-order, pseudo-second-order, and intra-particle diffusion models were applied to analyze the experimental data shown in Fig. 5. According to Table 2, by using the linearized form and plotting the $\ln \left(q_{\mathrm{e}}-q_{t}\right)$ versus $t$ (Eq. 6), $\frac{t}{q_{\mathrm{t}}}$ versus $t$ (Eq. 7), and $q_{t}$ versus $t^{0.5}$ (Eq. 8), for pseudo-first-order, pseudo-second-order, and intra-particle diffusion, respectively, the adsorption kinetics parameters were obtained at the temperature of $25{ }^{\circ} \mathrm{C}$. The coefficient of determination of the pseudo-second-order for nitrate and phosphate was 0.9997 and 0.9914 , respectively, which is close to 1 and the calculated $q_{\mathrm{e}}$ for nitrate and phosphate was in accordance with the experimental data. The linearity of the intra-particle diffusion model indicates the involvement of the intra-particle diffusion in the adsorption process. Passage of linear line through the origin indicates that the intra-particle diffusion is the rate-controlling step; else the rate of adsorption is controlled by the boundary layer and other kinetic models. According to Table 5, intra-particle diffusion is not in accordance with the experimental data, and thus, the rate of adsorption is not controlled by this model [37]. The pseudo-first-order model was determined to be the most suitable model for nitrate adsorption in the presence of competitor anions, with the coefficient of determination of 0.9922 . On the contrary, the pseudo-second-order model was determined to be a suitable model for phosphate adsorption in the presence of competitor anion, with the coefficient of determination value of 0.996 . The pseudo-second-order model considers that there is no external and internal mass transfer resistance in the adsorption procedure [35]. These results indicate that physical and chemical adsorption could be included in the adsorption.
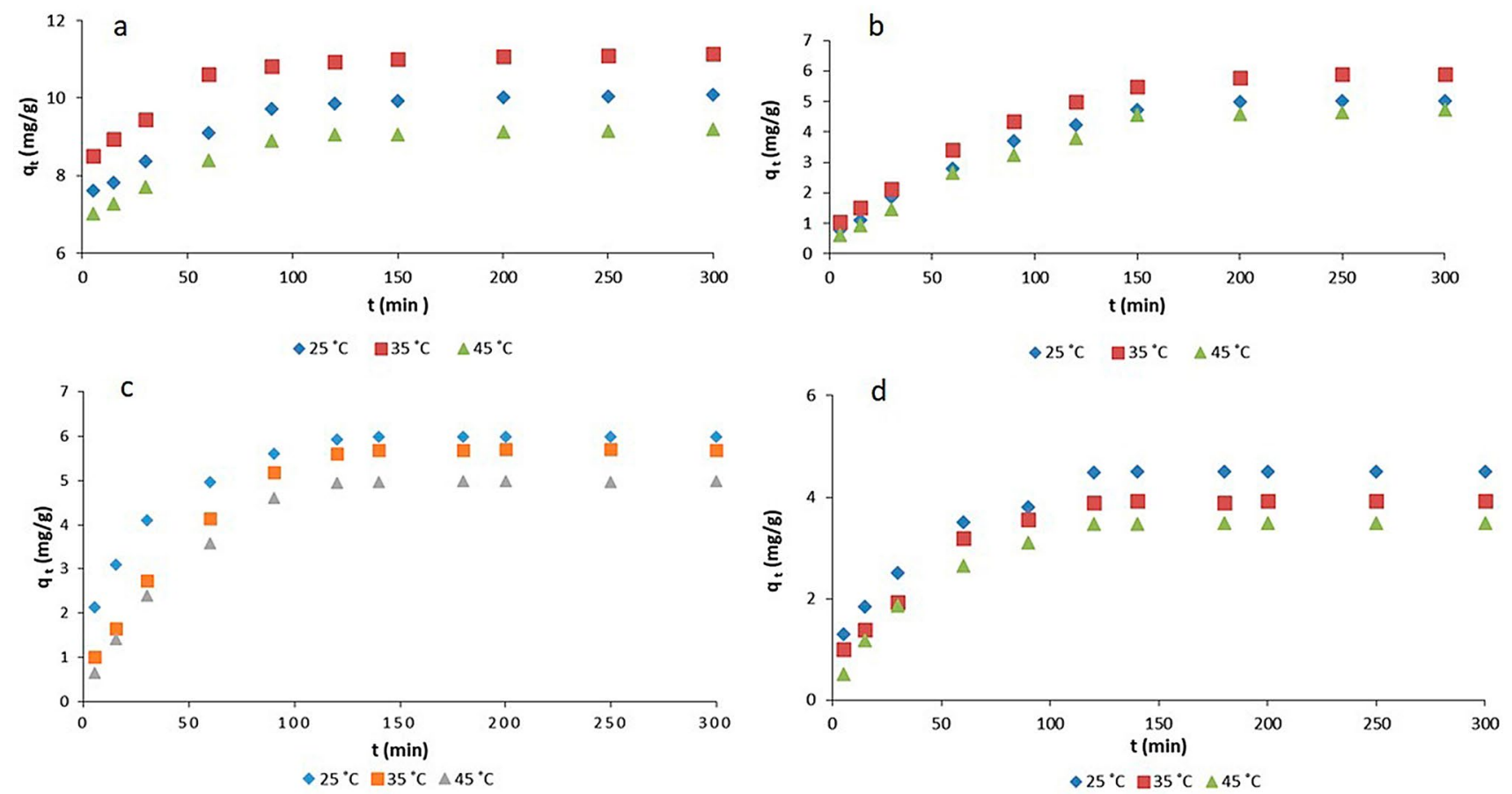

Fig. 5 Adsorption kinetics of a nitrate, $\mathbf{b}$ nitrate with competitor anions, $\mathbf{c}$ phosphate, $\mathbf{d}$ phosphate with competitor anions 
Table 5 Kinetic parameters for adsorption on the activated carbon from GGR at $298 \mathrm{~K}$

\begin{tabular}{|c|c|c|c|c|}
\hline Kinetic models & Analyte & $K_{1}\left(\min ^{-1}\right)$ & $q_{\mathrm{e}}(\mathrm{cal})$ & $R^{2}$ \\
\hline \multirow[t]{3}{*}{ Pseudo-first order } & Nitrate $\left(50 \mathrm{mg} \mathrm{L}^{-1}\right)$ & 0.0176 & 3.9 & 0.9814 \\
\hline & Phosphate $\left(40 \mathrm{mg} \mathrm{L}^{-1}\right)$ & 0.0293 & 4.75 & 0.9888 \\
\hline & $\begin{array}{l}\text { Nitrate }\left(50 \mathrm{mg} \mathrm{L}^{-1}\right)+\left(100 \mathrm{mg} \mathrm{L}^{-1} \mathrm{HCO}_{3}^{-}+\right. \\
\left.50 \mathrm{mg} \mathrm{L}^{-1} \mathrm{SO}_{4}^{2-}\right)\end{array}$ & 0.0147 & 4.8544 & 0.9922 \\
\hline \multirow[t]{4}{*}{ Pseudo-second order } & Analyte & $K_{2}\left(\mathrm{~g} \mathrm{mg}^{-1} \mathrm{~min}^{-1}\right)$ & $q_{\mathrm{e}}(\mathrm{cal})$ & $R^{2}$ \\
\hline & Nitrate $\left(50 \mathrm{mg} \mathrm{L}^{-1}\right)$ & 0.02 & 10.2354 & 0.9997 \\
\hline & Phosphate $\left(40 \mathrm{mg} \mathrm{L}^{-1}\right)$ & 0.004943 & 6.51 & 0.9914 \\
\hline & $\begin{array}{l}\text { Phosphate }\left(40 \mathrm{mg} \mathrm{L}^{-1}\right)+\left(100 \mathrm{mg} \mathrm{L}^{-1}\right. \\
\left.\mathrm{HCO}_{3}^{-}+50 \mathrm{mg} \mathrm{L}^{-1} \mathrm{SO}_{4}^{2-}\right)\end{array}$ & 0.0099 & 4.91 & 0.996 \\
\hline \multirow[t]{3}{*}{ Interparticle diffusion } & Analyte & $K_{\text {int }}\left(\mathrm{mg} \mathrm{g}^{-1} \min ^{-05}\right)$ & $C\left(\mathrm{mg} \mathrm{g}^{-1}\right)$ & $R^{2}$ \\
\hline & Nitrate $\left(50 \mathrm{mg} \mathrm{L}^{-1}\right)$ & 0.1794 & 7.4948 & 0.8643 \\
\hline & Phosphate $\left(40 \mathrm{mg} \mathrm{L}^{-1}\right)$ & 0.2497 & 2.5065 & 0.82 \\
\hline
\end{tabular}

Bolded words show the boundary of tables or adsorption mechanisms

\subsubsection{Response surface methodology}

The CCD with three levels and three parameters (A: initial concentration of nitrate or phosphate $\mathrm{mg} \mathrm{L}^{-1}, \mathrm{~B}: \mathrm{pH}, \mathrm{C}$ : Temperature ${ }^{\circ} \mathrm{C}$ ) was accomplished by using the DesignExpert software 7.0.0 (Stat-Ease Inc., Minneapolis). The number of experiments for each of nitrate and phosphate was 20 with 6 central point experiments. The results are tabulated in Table 6. A quadratic model was obtained for the prediction of nitrate removal, and a polynomial model was obtained for the prediction of phosphate removal. The analysis of variance (ANOVA) was used for the evaluation of the regression coefficients, and parameters of the model. Furthermore, it was applied for the determination of a mathematical model. The adequacy of the model was determined through the evaluation of the $F$ value, $p$
Table 6 (a) Design matrix and the responses obtained from the CCD for nitrate adsorption, (b) design matrix and the responses obtained from the CCD for phosphate adsorption

\begin{tabular}{|c|c|c|c|c|c|c|c|c|c|}
\hline \multicolumn{5}{|l|}{ a } & \multicolumn{5}{|l|}{ b } \\
\hline No. & $C_{0}\left(\mathrm{mg} \mathrm{L}^{-1}\right)$ & $\mathrm{pH}$ & $\begin{array}{l}\text { Tempera- } \\
\text { ture }\left({ }^{\circ} \mathrm{C}\right)\end{array}$ & $R_{N} \%$ & No. & $C_{0}\left(\mathrm{mg} \mathrm{L}^{-1}\right)$ & $\mathrm{pH}$ & $\begin{array}{l}\text { Tempera- } \\
\text { ture }\left({ }^{\circ} \mathrm{C}\right)\end{array}$ & $R_{p} \%$ \\
\hline 1 & 60.00 & 6.00 & 35 & 82.28 & 1 & 20.00 & 10.00 & 25 & 84.71 \\
\hline 2 & 60.00 & 6.00 & 35 & 82.41 & 2 & 60.00 & 7.00 & 25 & 79.015 \\
\hline 3 & 20.00 & 6.00 & 35 & 85.28 & 3 & 60.00 & 7.00 & 35 & 82.12 \\
\hline 4 & 100.00 & 10.00 & 45 & 72.16 & 4 & 60.00 & 7.00 & 35 & 81.81 \\
\hline 5 & 60.00 & 6.00 & 25 & 80.28 & 5 & 100.00 & 10.00 & 25 & 68.66 \\
\hline 6 & 60.00 & 10.00 & 35 & 82.16 & 6 & 20.00 & 10.00 & 45 & 70.19 \\
\hline 7 & 20.00 & 2.00 & 45 & 86.17 & 7 & 20.00 & 7.00 & 35 & 87.44 \\
\hline 8 & 100.00 & 6.00 & 35 & 78.16 & 8 & 100.00 & 4.00 & 25 & 78.36 \\
\hline 9 & 100.00 & 10.00 & 25 & 74.16 & 9 & 60.00 & 7.00 & 35 & 81.41 \\
\hline 10 & 60.00 & 6.00 & 35 & 83.06 & 10 & 60.00 & 4.00 & 35 & 91.71 \\
\hline 11 & 60.00 & 2.00 & 35 & 87.16 & 11 & 100.00 & 4.00 & 45 & 62.11 \\
\hline 12 & 60.00 & 6.00 & 45 & 78.16 & 12 & 100.00 & 7.00 & 35 & 62.33 \\
\hline 13 & 60.00 & 6.00 & 35 & 82.3 & 13 & 60.00 & 7.00 & 35 & 83.4 \\
\hline 14 & 20.00 & 2.00 & 25 & 86.56 & 14 & 100.00 & 10.00 & 45 & 57.69 \\
\hline 15 & 100.00 & 2.00 & 25 & 81.16 & 15 & 60.00 & 10.00 & 35 & 77.02 \\
\hline 16 & 60.00 & 6.00 & 35 & 82.61 & 16 & 60.00 & 7.00 & 45 & 68.32 \\
\hline 17 & 60.00 & 6.00 & 35 & 82.4 & 17 & 60.00 & 7.00 & 35 & 80.67 \\
\hline 18 & 20.00 & 10.00 & 25 & 82.74 & 18 & 20.00 & 4.00 & 25 & 94.38 \\
\hline 19 & 20.00 & 10.00 & 45 & 84.52 & 19 & 60.00 & 7.00 & 35 & 79.98 \\
\hline 20 & 100.00 & 2.00 & 45 & 77.16 & 20 & 20.00 & 4.00 & 45 & 79.16 \\
\hline
\end{tabular}


Table 7 The response surface method analysis of variance (ANOVA) for nitrate adsorption

\begin{tabular}{|c|c|c|c|c|c|}
\hline Source & $\begin{array}{l}\text { Sum of } \\
\text { squares }\end{array}$ & $d f$ & $F$ value & Prob $>F$ & \\
\hline Model & 293.07 & 9 & 151.64 & $<0.0001$ & Significant \\
\hline$A-C_{0}$ & 180.37 & 1 & 839.92 & $<0.0001$ & \\
\hline$B-\mathrm{pH}$ & 50.4 & 1 & 235.11 & $<0.0001$ & \\
\hline $\begin{array}{l}C \text {-tempera- } \\
\text { ture }\end{array}$ & 4.53 & 1 & 21.09 & 0.0010 & \\
\hline$A B$ & 5.33 & 1 & 24.82 & 0.0006 & \\
\hline$A C$ & 6.83 & 1 & 31.79 & 0.0002 & \\
\hline$B C$ & 2.17 & 1 & 10.12 & 0.0098 & \\
\hline$A^{2}$ & 1.72 & 1 & 8.01 & 0.0178 & \\
\hline$B^{2}$ & 12.70 & 1 & 59.14 & $<0.0001$ & \\
\hline$C^{2}$ & 29.78 & 1 & 138.69 & $<0.0001$ & \\
\hline Residual & 2.15 & 10 & & & \\
\hline Lack of fit & 1.72 & 5 & 4 & 0.0772 & $\begin{array}{l}\text { Not sig- } \\
\text { nificant }\end{array}$ \\
\hline Pure error & 0.43 & 5 & & & \\
\hline $\begin{array}{l}\text { Corrected } \\
\text { total }\end{array}$ & 295.22 & 19 & & & \\
\hline
\end{tabular}

value, $R^{2}, R_{\text {Adjusted }}^{2}$ and $R_{\text {Predicted. Equations } 15 \text { and } 16 \text { are }}^{2}$ quadratic and polynomial models in terms of actual factors for the prediction of nitrate and phosphate removal, respectively.

According to Table 7, the $F$ value (151.64) and $P$ value $(<0.0001)$ of the predicted model for nitrate indicate that the model is significant. The $F$ value of each term of this model is high, indicating the significance of each term of the model, and each parameter had an impact on the nitrate removal. The lack of fit of the model (LOF) is 0.0772 , which indicates that the LOF is not significant. Based on Table 7, terms of $A, B$, and $C^{2}$ had $F$ values of 839.92, 235.11,
Table 8 The response surface method analysis of variance (ANOVA) for phosphate adsorption

\begin{tabular}{|c|c|c|c|c|c|}
\hline Source & $\begin{array}{l}\text { Sum of } \\
\text { squares }\end{array}$ & $d f$ & $F$ value & Prob $>F$ & \\
\hline Model & 1777.19 & 8 & 50.95 & $<0.0001$ & Significant \\
\hline$A-C_{0}$ & 315.26 & 1 & 72.31 & $<0.0001$ & \\
\hline$B-\mathrm{pH}$ & 225.15 & 1 & 51.64 & $<0.0001$ & \\
\hline $\begin{array}{l}C \text {-tempera- } \\
\text { ture }\end{array}$ & 457.72 & 1 & 104.98 & $<0.0001$ & \\
\hline$A C$ & 0.79 & 1 & 0.18 & 0.6778 & \\
\hline$A^{2}$ & 68.75 & 1 & 15.77 & 0.0022 & \\
\hline$B^{2}$ & 55.19 & 1 & 12.66 & 0.0045 & \\
\hline$C^{2}$ & 106.31 & 1 & 24.38 & 0.0004 & \\
\hline$A C^{2}$ & 37.67 & 1 & 8.64 & 0.0135 & \\
\hline Residual & 47.96 & 11 & & & \\
\hline Lack of fit & 40.89 & 6 & 4.82 & 0.0572 & $\begin{array}{l}\text { Not sig- } \\
\text { nificant }\end{array}$ \\
\hline Pure error & 7.07 & 5 & & & \\
\hline $\begin{array}{l}\text { Corrected } \\
\text { total }\end{array}$ & 1825.14 & 19 & & & \\
\hline
\end{tabular}

and 138.69 , respectively, indicating that these terms had the highest impact on the nitrate removal efficiency. Based on Table 8, the predicted model for phosphate removal efficiency has an $F$ value of 50.95 and a $P$ value of $<0.001$, demonstrating the significance of the model. The $F$ values of each term of the mathematic model was high, and thus, each term had a significant influence on the phosphate removal efficiency. The LOF is 0.0572 which is not significant, which shows that the model fits. The terms of $A C^{2}$ and $A C$ were added to obtain higher $F$ value. The terms $C, A$, and $B$ had the $F$ values of $104.98,72.31$, and 51.64, respectively, showing that these terms had the highest impact on the phosphate removal efficiency. Figure 6 demonstrates the predicted values of nitrate and phosphate removal versus the experimental data.

$$
\begin{aligned}
N_{\text {removal }} \%= & 53.4+0.0646 C_{0}-2.323 \mathrm{pH}+2.296 \text { Temperature } \\
& -0.0051\left(C_{0} \cdot \mathrm{pH}\right)-0.0023\left(C_{0} \cdot \text { Temperature }\right)+0.013(\mathrm{pH} \cdot \text { Temperature }) \\
& -4.94 C_{0}^{2}+0.134 \mathrm{pH}^{2}-0.0329 \text { Temperature } \\
P_{\text {removal }} \%= & -16.077+1.519 C_{0}-8.55 \mathrm{pH}+8.723 \text { Temperature } \\
& -0.0841\left(C_{0} \cdot \text { Temperature }\right)-0.00312 C_{0}^{2}+0.4977 \mathrm{pH}^{2}-0.139 \text { Temperature }^{2} \\
& +0.001213\left(C_{0} \cdot \text { Temperature }^{2}\right)
\end{aligned}
$$



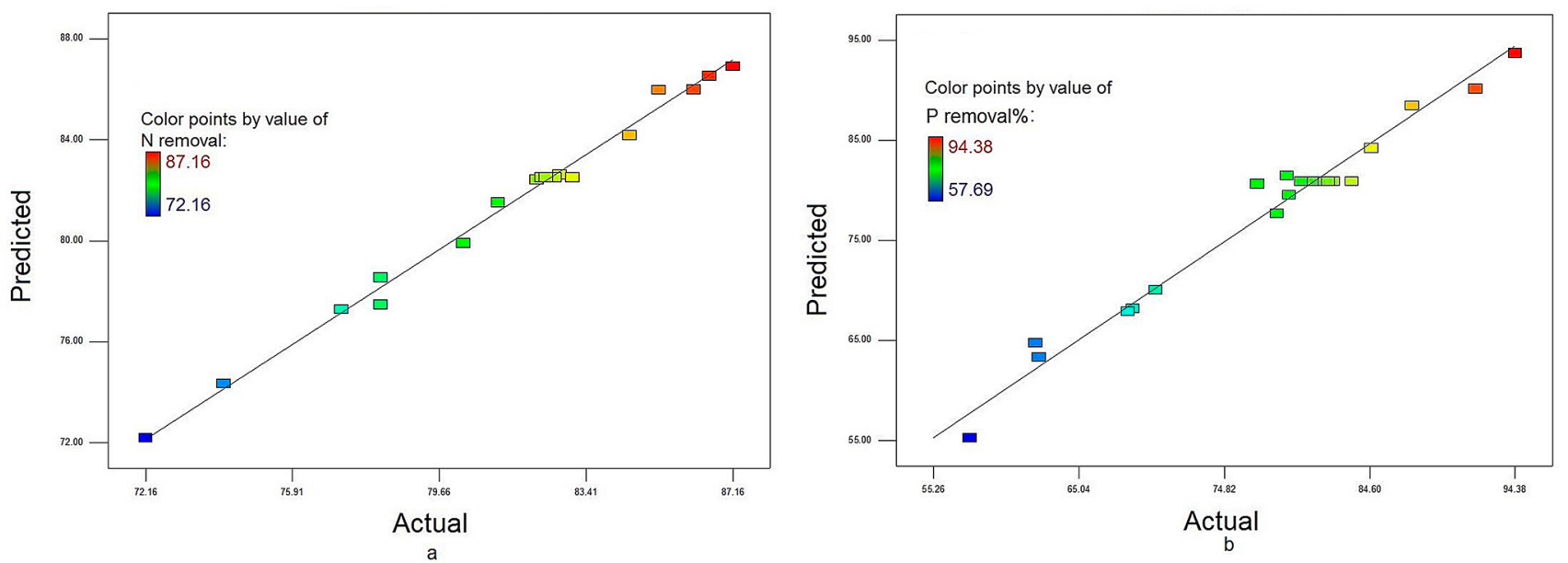

Fig. 6 Predicted versus actual for a nitrate removal, and $\mathbf{b}$ phosphate removal

Table 9 (a) Statistical parameters for the nitrate adsorption obtained from Eq. 15, b statistical parameters for the phosphate adsorption obtained from Eq. 16

\begin{tabular}{lcll}
\hline$a$ & & $b$ & \\
$R^{2}$ & 0.9927 & $R^{2}$ & 0.9737 \\
$R_{\text {Adjusted }}^{2}$ & 0.9862 & $R_{\text {Adjusted }}^{2}$ & 0.9546 \\
$R_{\text {Predicted }}^{2}$ & 0.9528 & $R_{\text {Predicted }}^{2}$ & 0.8112 \\
Adequate precision & 44.905 & Adequate Precision & 27.433 \\
\hline
\end{tabular}

According to Table 9, the regression coefficients $R^{2}$ were obtained to be 0.9927 and 0.9737 for nitrate and phosphate removal, respectively. The $R_{\text {Adjusted }}^{2}$ was determined to be 0.9862 and 0.9546 for nitrate and phosphate removal, respectively, and these values are close to 1 . The statistical suitability of the model is determined from the closeness of the $R_{\text {Adjusted }}^{2}$ values to the $R^{2}$ [43]. The value of adequate precision of 44.905 and 27.433 (which are greater than 4), for nitrate removal and phosphate removal, respectively, indicates an adequate signal.

According to Fig. 7, increasing the $\mathrm{pH}$ of nitrate and phosphate solution causes a reduction in nitrate and phosphate removal efficiency. The $\mathrm{pH}$ is the main controlling parameter in the electrostatic interaction between the adsorbate and the adsorbent [9]. An increase in $\mathrm{pH}$ increases the hydroxyl ions, leading to competition between the hydroxyl group and nitrate and phosphate anions for the adsorbent sites, which decreases the nitrate and phosphate removal. At low $\mathrm{pH}$, protons are present and the negativity of the surface of GGR activated carbon reduces. Therefore, the number of positively charged sites increases, which enhances adsorption [37, 38]. By increasing the initial solution concentration of nitrate and phosphate, the removal efficiencies decrease. This is due to the faster rate of occupation of active sites of adsorbent which reduces the adsorption capacity [20]. Initially, by increasing the temperature the nitrate and phosphate removal increases, however, a further increase in temperature results in the reduction of nitrate and phosphate removal efficiencies. This effect is attributed to the endothermic adsorption at low temperatures and the physical adsorption mechanism at high temperatures [9].

According to Fig. $8 \mathrm{a}, \mathrm{c}$ (the perturbation plot for the nitrate and phosphate removal), parameter $\mathrm{A}$ (the initial concentration of nitrate or phosphate) has the highest impact on the removal, followed by the $\mathrm{pH}$ and the temperature parameters. According to Fig. $8 \mathrm{~b}$, at low initial nitrate concentration, increasing the temperature increases the removal efficiency. However, by increasing the temperature at high initial nitrate concentration, the removal efficiency decreases. Based on Fig. $8 d$, at the low initial concentration of phosphate, increasing the temperature, increases the removal of phosphate, until an optimum temperature is reached at $32{ }^{\circ} \mathrm{C}$. By increasing the temperature further than the optimum point, the phosphate removal efficiency decreases. For high initial concentrations of phosphate, increasing the temperature decreases the phosphate removal efficiency.

\subsubsection{Adsorption isotherm}

Adsorption isotherm tests were carried out at the $\mathrm{pH}$ of 2 and 4 for nitrate and phosphate removal, respectively. The Langmuir (Eq. 9), Freundlich (Eq. 10), and Temkin (Eq. 11) in Table 2 were applied to the experimental data. The constant of isotherms for nitrate and phosphate is given in Table 10. The experimental data were in good accordance with the Langmuir isotherm, which had the highest linear regression coefficient. The maximum adsorption capacity obtained for nitrate at $308 \mathrm{~K}$ was $142.58 \mathrm{mg} \mathrm{g}^{-1}$ with the 

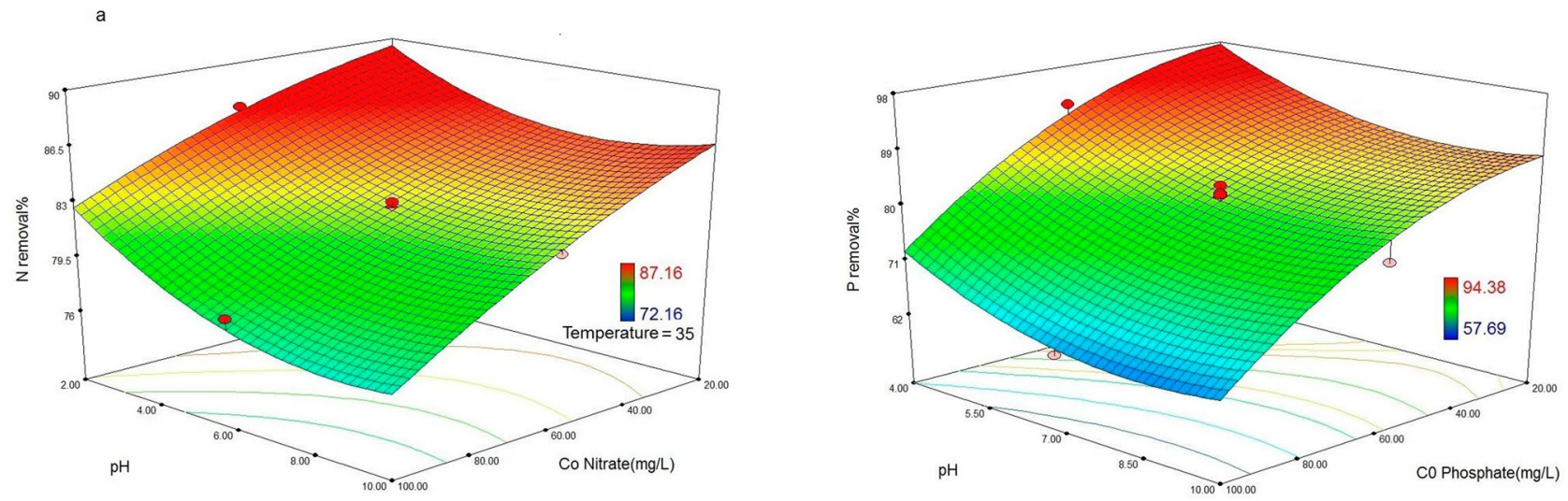

$b$
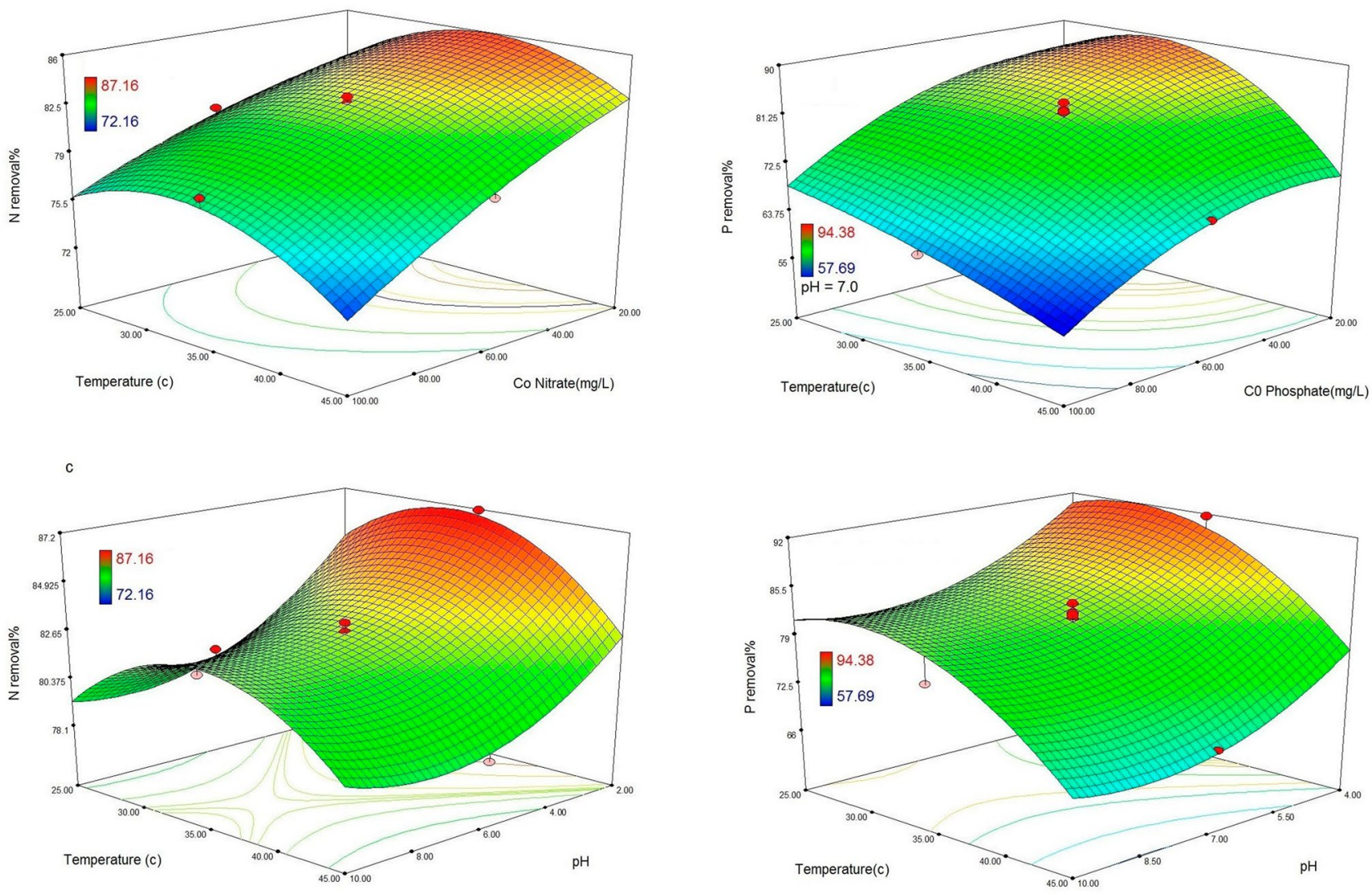

Fig. 7 Response surface plot of nitrate removal ( $\mathrm{N}$ removal) and phosphate removal ( $\mathrm{P}$ removal) showing the effect of a $\mathrm{pH}$ and initial concentration for nitrate and phosphate removal, b tempera-

linear regression coefficient of 0.9977 (Fig. 9a), and the maximum adsorption capacity for phosphate at $298 \mathrm{~K}$ was $92.59 \mathrm{mg} \mathrm{g}^{-1}$, with the linear regression coefficient of 0.9804 (Fig. 9c). The high linear regression coefficient demonstrates the monolayer adsorption of this process. Langmuir isotherm is evaluated by the separation factor $\left(R_{\mathrm{L}}\right)$, which is given in Eq. 17. The shape of isotherm is demonstrated with the $R_{\mathrm{L}}$, and an $R_{\mathrm{L}}$ value between 0 and

ture and initial concentration for nitrate and phosphate removal, and $\mathrm{c}$ temperature and $\mathrm{pH}$ on nitrate and phosphate removal

1 is indicative of favorable adsorption, whereas $R_{\mathrm{L}}$ value greater than 1 and $R_{\mathrm{L}}=0$ indicate irreversible adsorption.

$$
R_{\mathrm{L}}=\frac{1}{1+K_{\mathrm{L}} C_{0}}
$$



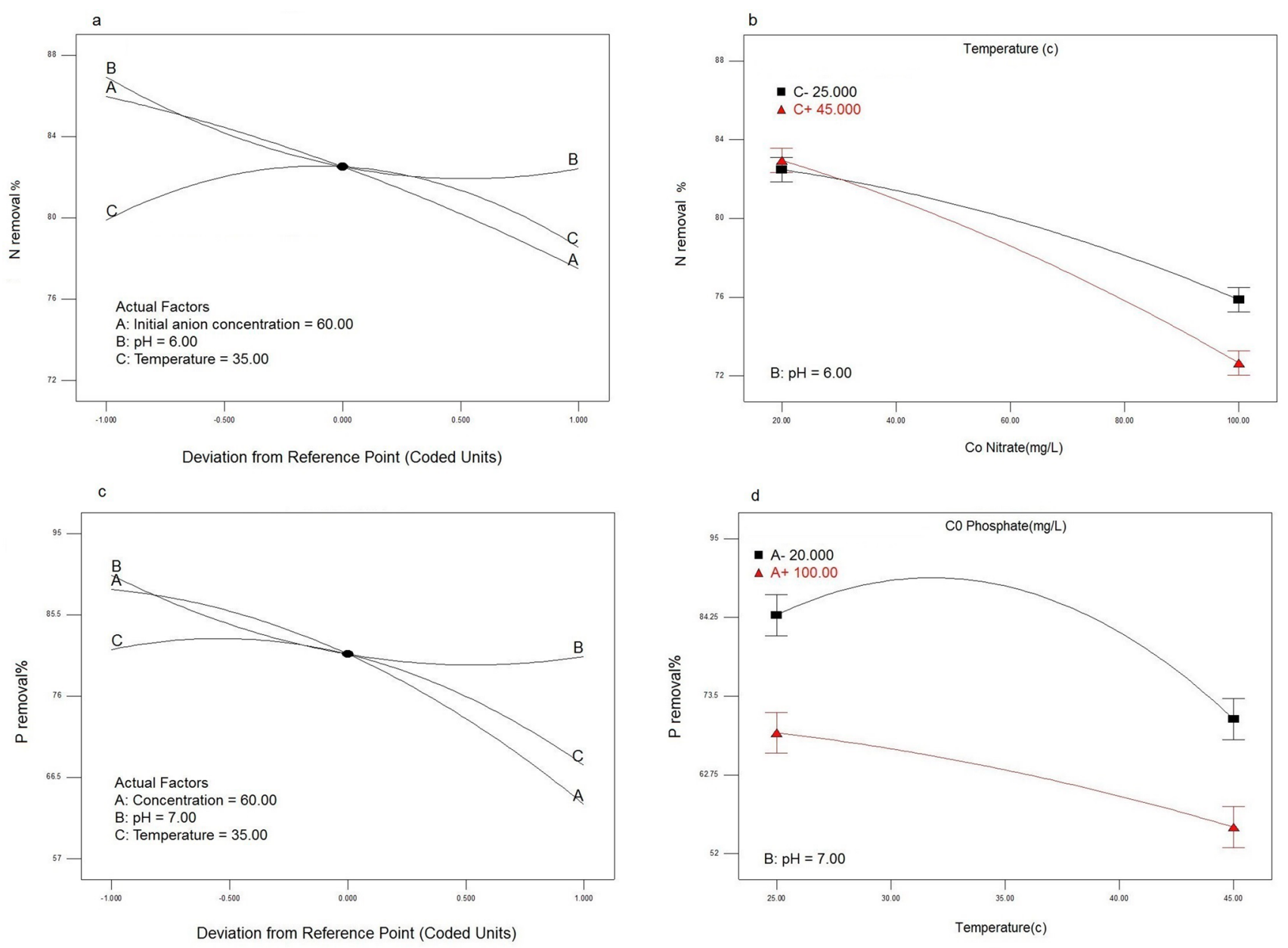

Fig. 8 a Perturbation plot for nitrate removal, $\mathbf{b}$ interaction of initial concentration and temperature parameters for nitrate removal, $\mathbf{c}$ perturbation plot for phosphate removal, $\mathbf{d}$ interaction of initial concentration and temperature for phosphate removal

Similarly, the isotherms were used to fit the experimental data of adsorption in the presence of competitor anions $100 \mathrm{mg} \mathrm{L}^{-1} \mathrm{HCO}_{3}^{-}+50 \mathrm{mg} \mathrm{L}^{-1} \mathrm{SO}_{4}^{2-}$. According to Fig. 9b, $\mathrm{d}$, the Langmuir isotherm was the best fit for the adsorption of nitrate and phosphate in the presence of competitor ions. The maximum adsorption capacity obtained for nitrate in the presence of competitor ion at $308 \mathrm{~K}$ was $47.39 \mathrm{mg} \mathrm{g}^{-1}$ with the linear regression coefficient of 0.984 (Fig. 9b), and the maximum adsorption capacity for phosphate at $298 \mathrm{~K}$ was $75.18 \mathrm{mg} \mathrm{g}^{-1}$, with the linear regression coefficient of 0.9834 (Fig. 9d). According to Table 11, the maximum adsorption capacity for nitrate and phosphate had decreased by $66 \%$, and $18 \%$, respectively, in the presence of competitor anions.

The presence of bicarbonate and sulfate anions occupied the active sites of the adsorbent and blocked the adsorption of nitrate and phosphate. Sulfate has two valance charges and thus adsorbs stronger than the nitrate with one valence charge. Therefore, the presence of sulfate anion strongly decreases the adsorption of nitrate.
However, the sulfate and bicarbonate anion have less tendency to adsorb in the presence of phosphate. Therefore, the presence of competitor anions $\left(100 \mathrm{mg} \mathrm{L}^{-1}\right.$ $\mathrm{HCO}_{3}^{-}+50 \mathrm{mg} \mathrm{L}^{-1} \mathrm{SO}_{4}^{2-}$ ) in the phosphate solution of $40 \mathrm{mg} \mathrm{L}^{-1}$ and does not significantly affect the adsorption of phosphate $[6,44]$.

\subsubsection{Adsorption thermodynamics}

The temperature behavior was studied to determine the adsorption thermodynamics and the nature of the adsorption process. The Gibbs free energy $\left(\Delta G^{\circ}, \mathrm{kJ} \mathrm{mol}^{-1}\right)$ was obtained from Eq. 18. In Eq. $18, R$ is the gas constant $\left(8.314 \mathrm{~J} \mathrm{~mol}^{-1} \mathrm{~K}^{-1}\right), T$ is the temperature $(\mathrm{K})$, and $K$ is from the $K_{\mathrm{L}}$ in the Langmuir isotherm $\left(\mathrm{L} \mathrm{mol}^{-1}\right)$. The $\Delta G^{\circ}$ for nitrate was obtained at 298,308 , and $318 \mathrm{~K}$ and was determined to be $-18.3,-20.1$, and $-20.8 \mathrm{~kJ} \mathrm{~mol}^{-1}$, respectively. The $\Delta G^{\circ}$ was determined to be $-16.7,-17.1$, and $-18.2 \mathrm{~kJ} \mathrm{~mol}^{-1}$ for phosphate removal at 298, 308, and $318 \mathrm{~K}$, respectively. The negative values attained 
Table 10 Isotherm parameters for adsorption from the activated carbon synthesized from GGR

\begin{tabular}{|c|c|c|c|c|c|c|}
\hline Isotherms & Temperature $K$ & Analyte & $K_{l}\left(\mathrm{~L} \mathrm{mg}^{-1}\right)$ & $q_{0}\left(\mathrm{mg} \mathrm{g}^{-1}\right)$ & $R^{2}$ & $R_{l}$ \\
\hline \multirow[t]{7}{*}{ Langmuir } & 298 & Nitrate $\left(50 \mathrm{mg} \mathrm{L}^{-1}\right)$ & 0.0285 & 136.98 & 0.9966 & 0.4123 \\
\hline & 308 & Nitrate & 0.0413 & 142.58 & 0.9977 & 0.3262 \\
\hline & 318 & Nitrate & 0.0423 & 128.20 & 0.9887 & 0.321 \\
\hline & 298 & Phosphate (40 $\mathrm{mg} \mathrm{L}^{-1}$ ) & $9.0429 \times 10^{-3}$ & 92.59 & 0.9804 & 0.734 \\
\hline & 308 & Phosphate & $8.2753 \times 10^{-3}$ & 84.03 & 0.9856 & 0.751 \\
\hline & 318 & Phosphate & 0.0103 & 79.92 & 0.9855 & 0.708 \\
\hline & & Analyte & $K_{\mathrm{F}}\left(\mathrm{mg}^{1-}\right.$ & $\left.L^{1 / n} g^{-1}\right)$ & & $R^{2}$ \\
\hline \multirow[t]{7}{*}{ Freundlich } & 298 & Nitrate $\left(50 \mathrm{mg} \mathrm{L}^{-1}\right)$ & 5.0319 & & & 0.9442 \\
\hline & 308 & Nitrate & 6.5646 & & & 0.9280 \\
\hline & 318 & Nitrate & 3.6659 & & & 0.9591 \\
\hline & 298 & Phosphate $\left(40 \mathrm{mg} \mathrm{L}^{-1}\right)$ & 1.2289 & & & 0.9632 \\
\hline & 308 & Phosphate & 1.0879 & & & 0.9675 \\
\hline & 318 & Phosphate & 1.3396 & & & 0.9597 \\
\hline & & Analyte & $K_{\mathrm{T}}\left(\mathrm{L} \mathrm{mg}^{-1}\right)$ & & & $R^{2}$ \\
\hline \multirow[t]{6}{*}{ Temkin } & 298 & Nitrate $\left(50 \mathrm{mg} \mathrm{L}^{-1}\right)$ & 0.9314 & & & 0.8417 \\
\hline & 308 & Nitrate & 0.8374 & & & 0.8723 \\
\hline & 318 & Nitrate & 0.6282 & & & 8262 \\
\hline & 298 & Phosphate (40 $\left.\mathrm{mg} \mathrm{L}^{-1}\right)$ & 3.5558 & & & 0.8728 \\
\hline & 308 & Phosphate & 4.0172 & & & 0.8879 \\
\hline & 318 & Phosphate & 3.3683 & & & 0.8973 \\
\hline
\end{tabular}

for $\Delta G^{\circ}$ indicate the spontaneous nature of adsorption. The enthalpy $\left(\Delta H^{\circ}, \mathrm{kJ} \mathrm{mol}^{-1}\right)$ and entropy change $\left(\Delta S^{\circ}\right.$, $\mathrm{J} \mathrm{mol}^{-1} \mathrm{~K}^{-1}$ ) were obtained from Eq. 19. The value of $\Delta H^{\circ}$ for nitrate and phosphate was obtained to be $15.55 \mathrm{~kJ} \mathrm{~mol}^{-1}$ and $5.12 \mathrm{~kJ} \mathrm{~mol}^{-1}$, respectively. The endothermic nature of adsorption is demonstrated by the positive value of enthalpy. The $\Delta S^{\circ}$ for nitrate and phosphate adsorption was $114.36 \mathrm{~J} \mathrm{~mol}^{-1} \mathrm{~K}^{-1}$ and $73.37 \mathrm{~J} \mathrm{~mol}^{-1} \mathrm{~K}^{-1}$, respectively. The positive values of $\Delta S^{\circ}$ propose the rise in randomness at the solid/solution interface of the adsorption process $[37,45]$.

$\Delta G^{\circ}=-R \cdot T \cdot \ln K$

$\ln K=\frac{\Delta S^{\circ}}{R}-\frac{\Delta H^{\circ}}{R T}$

\subsection{Fixed-bed adsorption studies}

One of the important parameters utilized in the design of the adsorption process is the length of the unused bed (LUB). The maximum allowable limit of nitrate and phosphate in the drinking water is $10 \mathrm{mg} \mathrm{L}^{-1}$ and $0.1 \mathrm{mg} \mathrm{L}^{-1}$, respectively $[46,47]$. The LUB values for the adsorption of nitrate and phosphate at different concentrations and flow rate were determined from the analysis of breakthrough curves (

Figure 10 and Eq. (3)) and are stated in Table 12. The LUB for constant nitrate concentration of $50 \mathrm{mg} \mathrm{L}^{-1}$ at the flow rate of $25 \mathrm{~mL} \mathrm{~min}^{-1}$ was obtained to be $2.07 \mathrm{~cm}$, and for constant phosphate concentration of $40 \mathrm{mg} \mathrm{L}^{-1}$ at the flow rate of $25 \mathrm{~mL} \mathrm{~min}{ }^{-1}$ was determined to be $4.43 \mathrm{~cm}$. The low value of LUB at high concentrations of nitrate and phosphate indicates high utilization of the GGR activated carbon bed capacity. A narrow mass transfer zone or small LUB is desirable to utilize the adsorbent efficiently and for the reduction in the cost of energy for regeneration [33].

Figure 10a, c demonstrates the breakthrough curves for the adsorption of nitrate and phosphate in the continuous fixed-bed column loaded with the GGR activated carbon. The adsorbent height in the column was kept at $10 \mathrm{~cm}$. According to Fig. 10 a, c, by increasing the flow rate for nitrate $\left(50 \mathrm{mg} \mathrm{L}^{-1}\right)$ and phosphate $\left(40 \mathrm{mg} \mathrm{L}^{-1}\right)$ from 10 to $40 \mathrm{~mL} \mathrm{~min}^{-1}$ the breakthrough time decreases from 76 to $41 \mathrm{~min}$, and 66 to $32 \mathrm{~min}$, respectively. When the flow rate is high, the adsorbate does not have sufficient time for diffusion inside the pores of the GGR activated carbon, and thus nitrate and phosphate leave the adsorption bed prior to reaching equilibrium, resulting in low utilization of the adsorption bed. At lower flow rates, nitrate and phosphate have a higher residence time in the adsorption 
a

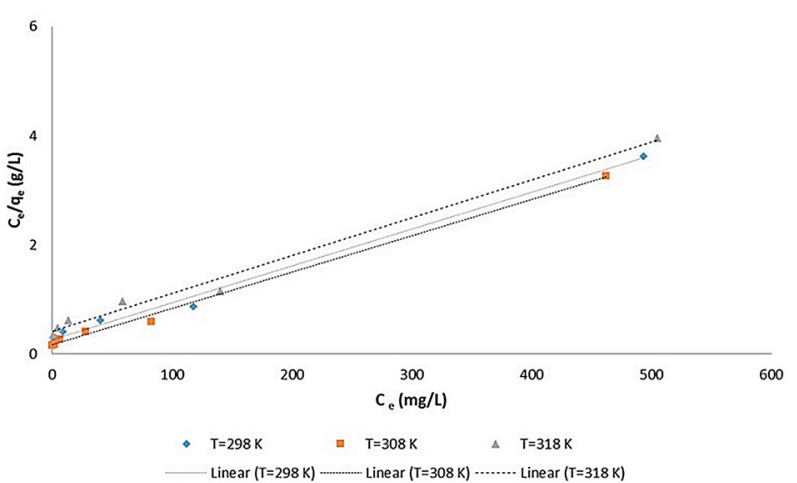

c

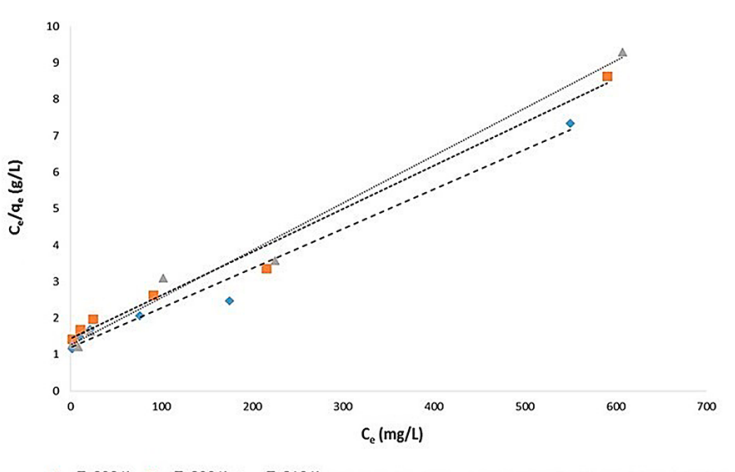

Fig. 9 Linearized Langmuir adsorption isotherm were obtained at $208 \mathrm{~K}, 308 \mathrm{~K}, 318 \mathrm{~K}$ and at $\mathrm{pH}$ of 2 for nitrate and pH of 4 for phosphate, $\mathbf{a}$ nitrate adsorption, $\mathbf{b}$ nitrate adsorption in the presence of b
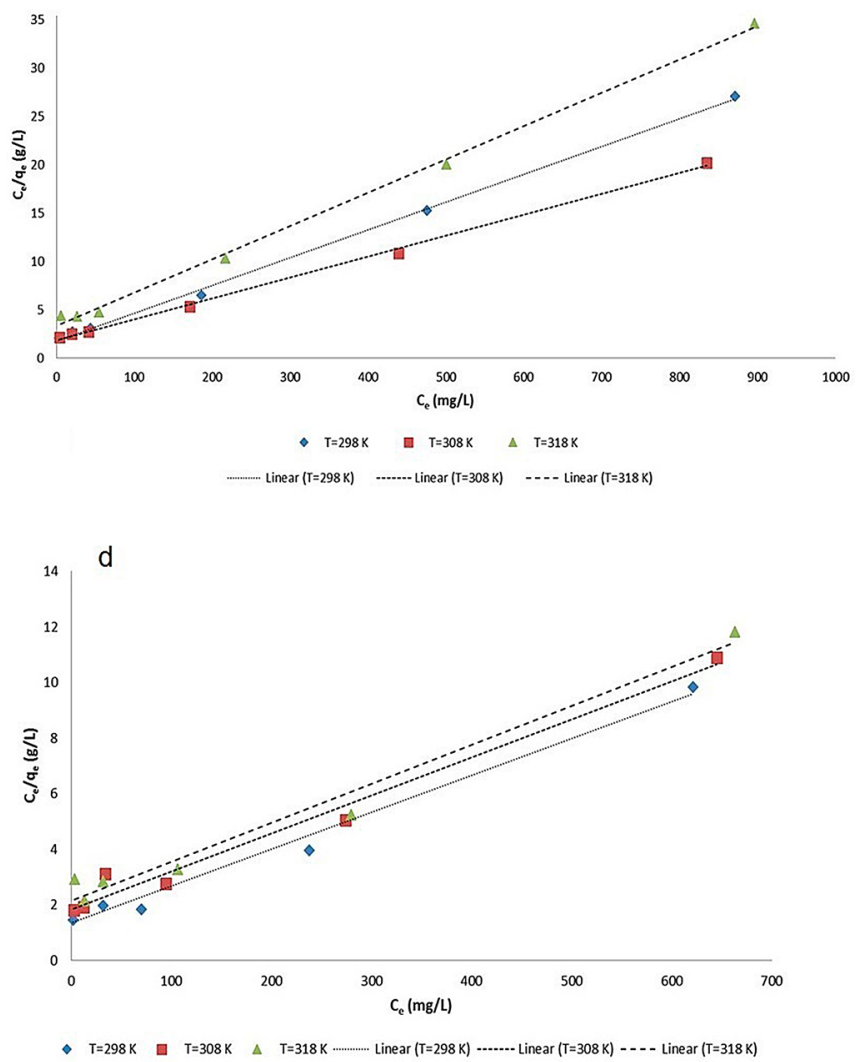

competitor anions, c phosphate adsorption, $\mathbf{d}$ phosphate adsorption in the presence of competitor anions

Table 11 Adsorption isotherms for nitrate and phosphate in the presence of competitor anions

\begin{tabular}{cllllll}
\hline Isotherms & Temperature $K$ & Analyte & $\left.K_{l}(\mathrm{~L} \mathrm{mg})^{-1}\right)$ & $q_{0}\left(\mathrm{mg} \mathrm{g}^{-1}\right)$ & $R^{2}$ & $R_{l}$ \\
\hline Langmuir & 298 & Nitrate $\left(50 \mathrm{mg} \mathrm{L}^{-1}\right)+\left(100 \mathrm{mg} \mathrm{L}^{-1} \mathrm{HCO}_{3}^{-}+50 \mathrm{mg} \mathrm{L}^{-1} \mathrm{SO}_{4}^{2-}\right)$ & 0.011 & 36.10 & 0.9901 & 0.645 \\
& 308 & Nitrate $\left(50 \mathrm{mg} \mathrm{L}^{-1}\right)+\left(100 \mathrm{mg} \mathrm{L}^{-1} \mathrm{HCO}_{3}^{-}+50 \mathrm{mg} \mathrm{L}^{-1} \mathrm{SO}_{4}^{2-}\right)$ & 0.0094 & 47.39 & 0.984 & 0.68 \\
& 318 & Nitrate $\left(50 \mathrm{mg} \mathrm{L}^{-1}\right)+\left(100 \mathrm{mg} \mathrm{L}^{-1} \mathrm{HCO}_{3}^{-}+50 \mathrm{mg} \mathrm{L}^{-1} \mathrm{SO}_{4}^{2-}\right)$ & 0.0091 & 29.49 & 0.9906 & 0.687 \\
298 & Phosphate $\left(40 \mathrm{mg} \mathrm{L}^{-1}\right)+\mathrm{HCO}_{3}^{-}\left(100 \mathrm{mg} \mathrm{L}^{-1}\right)+\mathrm{SO}_{4}^{2-}\left(50 \mathrm{mg} \mathrm{L}^{-1}\right)$ & $9.87 \times 10^{-3}$ & 75.18 & 0.9834 & 0.716 \\
308 & Phosphate $\left(40 \mathrm{mg} \mathrm{L}^{-1}\right)+\left(100 \mathrm{mg} \mathrm{L}^{-1} \mathrm{HCO}_{3}^{-}+50 \mathrm{mg} \mathrm{L}^{-1} \mathrm{SO}_{4}^{2-}\right)$ & $7.47 \times 10^{-3}$ & 72.99 & 0.9805 & 0.7699 \\
& 318 & Phosphate $\left(40 \mathrm{mg} \mathrm{L}^{-1}\right)+\left(100 \mathrm{mg} \mathrm{L}^{-1} \mathrm{HCO}_{3}^{-}+50 \mathrm{mg} \mathrm{L}^{-1} \mathrm{SO}_{4}^{2-}\right)$ & $6.5 \times 10^{-3}$ & 71.42 & 0.9763 & 0.793 \\
\hline
\end{tabular}

bed, allowing a more efficient separation. Furthermore, by increasing the flow rate the breakthrough curve changes from concave-up to concave-down in the mid-ranges of time. This is because at low flow rate values the transport process is limited by the interparticle diffusion and the external mass transfer is slow, thus the adsorption rate is lower, and the length of the mass transfer zone would be longer [33].

The effect of the inlet concentration of nitrate and phosphate at 20,60 , and $100 \mathrm{mg} \mathrm{L}^{-1}$ at the flow rate of

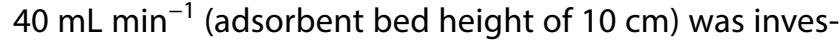
tigated. According to Fig. 10b, d, as the inlet concentration increases, the breakthrough curve becomes sharper. The breakthrough time decreases from 70 to $20 \mathrm{~min}$, as the inlet concentration of nitrate increases from 20 to $100 \mathrm{mg} \mathrm{L}^{-1}$, and decreases from 45 to $25 \mathrm{~min}$ as the phosphate inlet concentration increases from 20 to $100 \mathrm{mg} \mathrm{L}^{-1}$. This is attributed to the rapid saturation of the adsorbent binding sites of the GGR activated carbon. 

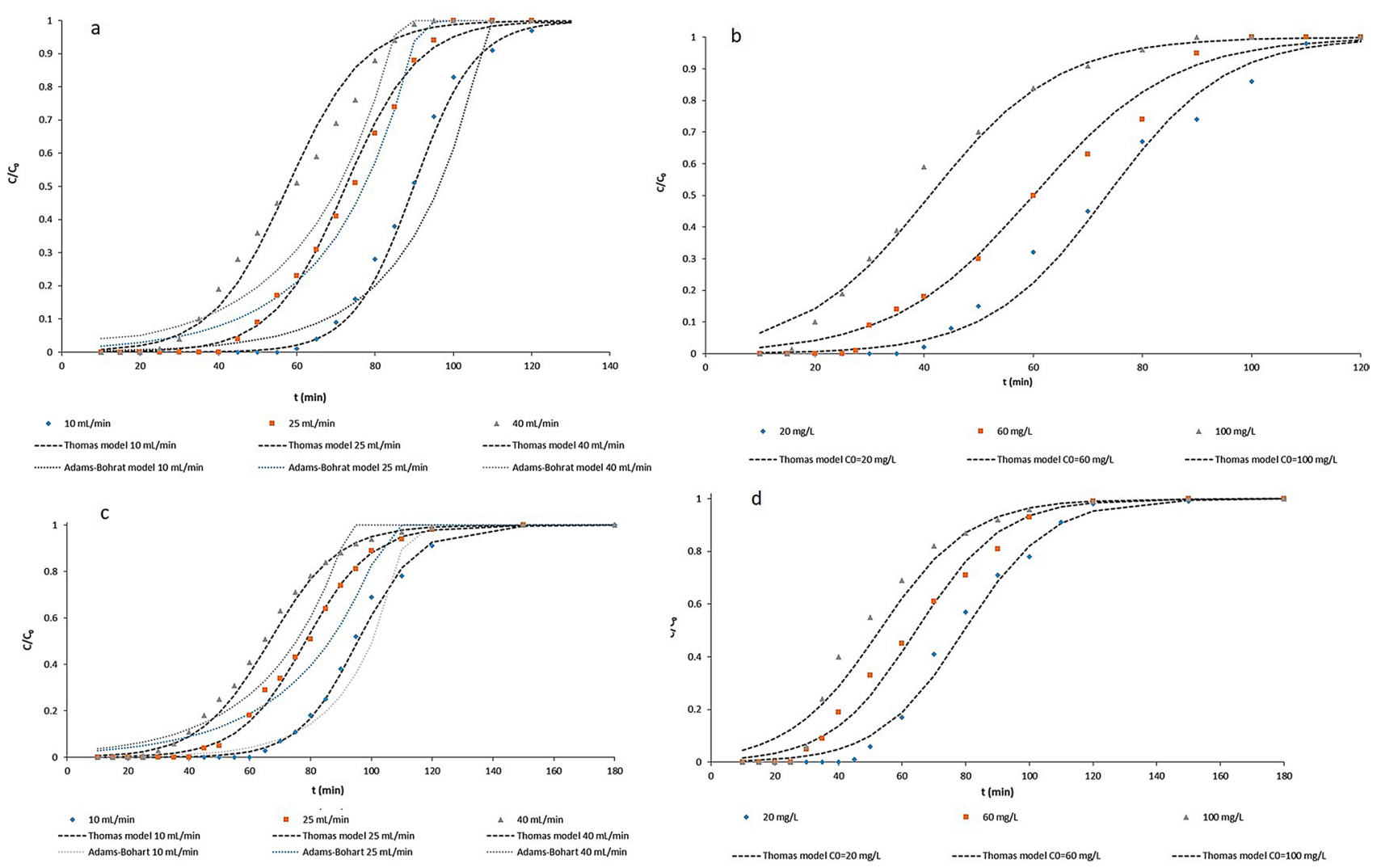

Fig. 10 The breakthrough curves a effect of volumetric flow rate at constant inlet concentration of nitrate $\left(50 \mathrm{mg} \mathrm{L}^{-1}\right)$, b effect of inlet concentration of nitrate at constant volumetric flow rate

$\left(40 \mathrm{~mL} \mathrm{~min}{ }^{-1}\right)$, c effect of volumetric flow rate at constant inlet concentration of phosphate $\left(40 \mathrm{mg} \mathrm{L}^{-1}\right)$, $\mathbf{d}$ effect of inlet concentration of phosphate at constant volumetric flow rate $\left(40 \mathrm{~mL} \mathrm{~min}{ }^{-1}\right)$
Table 12 (a) LUB for nitrate and phosphate removal at constant $C_{0}$ (b) LUB for nitrate and phosphate removal at constant $Q$ (volumetric flow rate)

\begin{tabular}{|c|c|c|c|c|c|c|c|}
\hline a & & & & $b$ & & & \\
\hline$C_{0}=50\left(\mathrm{mg} \mathrm{L}^{-1}\right)$ & & & & $Q=40\left(\mathrm{~mL} \mathrm{~min}^{-1}\right)$ & & & \\
\hline$Q\left(\mathrm{~mL} \min ^{-1}\right)$ & 10 & 25 & 40 & $\overline{C_{0}\left(\mathrm{mg} \mathrm{L}^{-1}\right)}$ & 20 & 60 & 100 \\
\hline $\operatorname{LUB}_{\text {Nitrate }}(\mathrm{cm})$ & 1.45 & 2.07 & 2.99 & $\operatorname{LUB}_{\text {Nitrate }}(\mathrm{cm})$ & 0.44 & 3.89 & 5.18 \\
\hline$C_{0}=40\left(\mathrm{mg} \mathrm{L}^{-1}\right)$ & & & & $Q=40\left(\mathrm{~mL} \mathrm{~min}^{-1}\right)$ & & & \\
\hline$Q\left(m L \min ^{-1}\right)$ & 10 & 25 & 40 & $C_{0}\left(\mathrm{mg} \mathrm{L}^{-1}\right)$ & 20 & 60 & 100 \\
\hline $\operatorname{LUB}_{\text {Phosphate }}(\mathrm{cm})$ & 3.13 & 4.43 & 5.18 & $\operatorname{LUB}_{\text {Phosphate }}(\mathrm{cm})$ & 4.35 & 6 & 7.42 \\
\hline
\end{tabular}

The behavior of the fixed-bed column was described with Adams-Bohart (Eq. 12), Thomas (Eq. 13), and Yoon-Nelson (Eq. 14) models (Table 2). The Adams-Bohart adsorption model was used to describe the first part of the breakthrough curve. According to Table 13, the values of $K_{A B}$ decrease with increasing the flow rate and decrease with increasing the concentration. Therefore, lower flow rate and lower influent concentration increase the adsorption of nitrate and phosphate in the column. The coefficient of determination values reveals that this model is not in accordance with the experimental data. By increasing the volumetric flow rate, the model was not suitable for fitting the experimental data; therefore, it is not reported in Fig. 10b, d. The values of $K_{\text {Th }}$ decrease with increasing the inlet concentrations of nitrate and phosphate. This is due to the presence of the driving force between the inlet concentration of nitrate and phosphate adsorbed on the adsorbent and the nitrate and phosphate in the solution. By increasing the flow rate, the $K_{\text {Th }}$ decreases, and the $m q_{0}$ increases. Therefore, lower inlet concentration and lower flow rate lead to higher adsorption of adsorbate in the column. Moreover, all the coefficients of determination for line fitting are more than 0.94 , demonstrating an exceptional confidence level. The $K_{\mathrm{YN}}$ demonstrates 
Table 13 Parameters of Adams-Bohart, Thomas, and Yoon-Nelson models under column adsorption process obtained from (a) nitrate removal breakthrough curve, (b) phosphate removal breakthrough curve

\begin{tabular}{|c|c|c|c|c|c|c|c|c|c|c|}
\hline \multirow[t]{2}{*}{$C_{0}\left(\mathrm{mg} \mathrm{L}^{-1}\right)$} & \multirow[t]{2}{*}{$Q\left(\mathrm{~mL} \min ^{-1}\right)$} & \multicolumn{3}{|c|}{ Adams-Bohart model } & \multicolumn{3}{|l|}{ Thomas model } & \multicolumn{3}{|c|}{ Yoon and Nelson model } \\
\hline & & $\begin{array}{l}K_{\mathrm{AB}} \times 10^{-4} \\
\left(\mathrm{~L} \mathrm{mg}{ }^{-1} \mathrm{~min}^{-1}\right)\end{array}$ & $N_{0}\left(\mathrm{mg} \mathrm{L}^{-1}\right)$ & $R^{2}$ & $\begin{array}{l}K_{\text {Th }} \\
\left(\mathrm{mL} \mathrm{min}^{-1} \mathrm{mg}^{-1}\right)\end{array}$ & $m q_{0}(\mathrm{mg})$ & $R^{2}$ & $K_{Y N}\left(\min ^{-1}\right)$ & $\begin{array}{l}\tau \\
(\min )\end{array}$ & $t_{\text {exp }}(\min )$ \\
\hline \multicolumn{11}{|l|}{$a$} \\
\hline 50 & 10 & 11.2 & 1730 & 0.83 & 0.0026 & 44,914 & 0.98 & 0.127 & 89 & 90 \\
\hline 50 & 25 & 9.92 & 3632 & 0.94 & 0.0022 & 90,621 & 0.98 & 0.107 & 72 & 75 \\
\hline 50 & 40 & 9.04 & 5156 & 0.84 & 0.0021 & 115,381 & 0.94 & 0.104 & 57 & 60 \\
\hline 20 & 40 & 17.8 & 2572 & 0.86 & 0.0046 & 58,811 & 0.95 & 0.092 & 73 & 72 \\
\hline 60 & 40 & 5.6 & 6913 & 0.92 & 0.0013 & 144,021 & 0.96 & 0.078 & 60 & 60 \\
\hline 100 & 40 & 3.3 & 8880 & 0.79 & 0.0009 & 164,418 & 0.98 & 0.085 & 41 & 39 \\
\hline \multicolumn{11}{|l|}{$b$} \\
\hline 40 & 10 & 15.17 & 1423 & 0.88 & 0.0025 & 38,228 & 0.98 & 0.1 & 95 & 94 \\
\hline 40 & 25 & 9.27 & 3343 & 0.79 & 0.0023 & 78,386 & 0.98 & 0.092 & 78 & 80 \\
\hline 40 & 40 & 10 & 4720 & 0.82 & 0.0021 & 106,316 & 0.94 & 0.084 & 66 & 65 \\
\hline 20 & 40 & 12.9 & 3462 & 0.54 & 0.0037 & 63,640 & 0.96 & 0.074 & 79 & 76 \\
\hline 60 & 40 & 5.05 & 8441 & 0.65 & 0.0012 & 154,683 & 0.98 & 0.072 & 64 & 64 \\
\hline 100 & 40 & 1.64 & 14,211 & 0.51 & 0.0007 & 211,558 & 0.95 & 0.07 & 52 & 47 \\
\hline
\end{tabular}
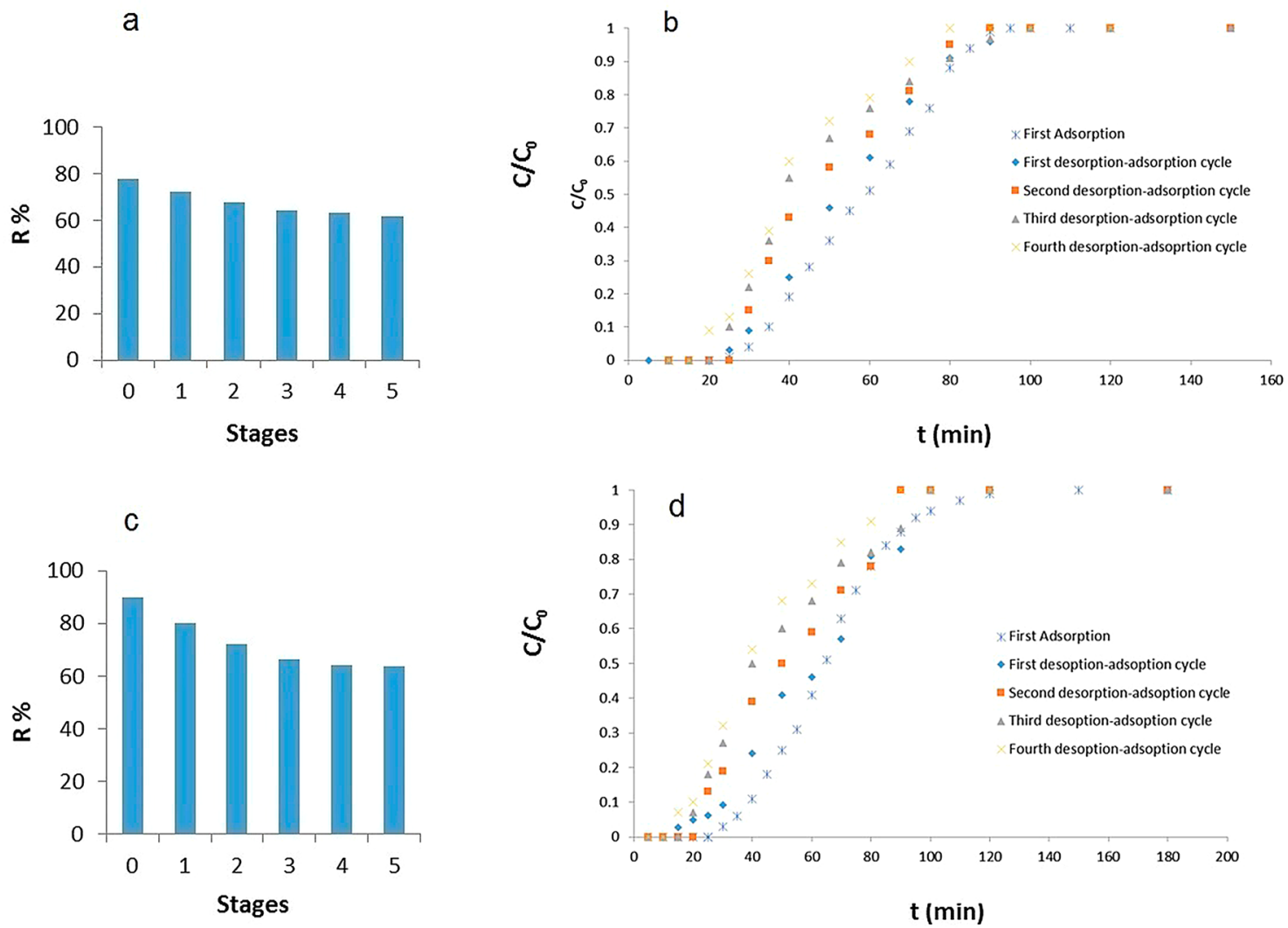

Fig. 11 Adsorption-desorption of a nitrate in the batch system, b nitrate in the fixed-bed column, $\mathbf{c}$ phosphate in the batch system, $\mathbf{d}$ phosphate in the fixed-bed column 
Table 14 Comparison of adsorption capacity of GGR activated carbon with the other adsorbents

\begin{tabular}{|c|c|c|c|}
\hline Adsorbent & Analyte & $q_{m}\left(\mathrm{mg} \mathrm{L}^{-1}\right)$ & References \\
\hline Rice husk & Nitrate & 86.2 & [7] \\
\hline Sugar beet bagasse & Nitrate & 27.5 & [37] \\
\hline Corncob & Nitrate & 49.9 & {$[6]$} \\
\hline Coconut copra & & 59.2 & \\
\hline Modified rice husk & Nitrate & 55 & {$[35]$} \\
\hline Calcined waste eggshell & Phosphate & 23 & [39] \\
\hline Zirconic chitosan beads & Phosphate & 61.7 & [9] \\
\hline $\mathrm{ZnCl}_{2}$ activated coir pith carbon & Phosphate & 5.1 & {$[32]$} \\
\hline Modified Wood-based activated carbon & Phosphate & 16 & {$[31]$} \\
\hline Modified granular activated carbon & Nitrate & 21.5 & {$[1]$} \\
\hline Activated carbons developed with potassium hydroxide & Nitrate & 18.6 & {$[48]$} \\
\hline Composite of activated carbon and $\mathrm{Fe}_{2} \mathrm{O}_{3}$ nanoparticles & Nitrate & 17.7 & {$[2]$} \\
\hline Activated carbon & Nitrate & 14.6 & {$[24]$} \\
\hline Activated carbon of residue & Phosphate & 30.2 & \\
\hline Bayoxide E33 (E33) & Phosphate & 37.7 & {$[8]$} \\
\hline E33/Agll & & 38.8 & \\
\hline Zinc chloride ( $\mathrm{ZnCl} 2$ )-treated coconut granular activated carbon & Nitrate & 10.3 & {$[10]$} \\
\hline \multirow[t]{2}{*}{ Mg-Al-layered double hydroxide } & Nitrate & 117 & [49] \\
\hline & Phosphate & 26.4 & \\
\hline Iron-zirconium modified activated carbon nanofiber & Phosphate & 26.3 & [15] \\
\hline Modified chitosan beads & phosphate & 61.7 & {$[9]$} \\
\hline \multirow[t]{2}{*}{ Activated carbon produced from Prosopis juliflora } & Phosphate & 13.55 & {$[50]$} \\
\hline & Nitrate & 10.99 & {$[50]$} \\
\hline Modified activated carbon from tobacco stalk & Phosphate & 41.6 & {$[51]$} \\
\hline Biochar from bamboo & Nitrate & 5 & {$[52]$} \\
\hline \multirow[t]{2}{*}{ Glycyrrhiza glabra residues activated carbon } & Nitrate & 142.5 & Present study \\
\hline & Phosphate & 92.5 & \\
\hline
\end{tabular}

the breakthrough curve shape. The values of $\tau$ were in accordance with the $t_{\exp }$ (time required for $50 \%$ adsorbate breakthrough). By increasing the flow rate and inlet concentration, $\tau$ decreases, as the saturation in the column takes place quickly $[6,33,40]$.

\subsection{Results of desorption studies}

According to Fig. $11 \mathrm{a}, \mathrm{c}$, by increasing the number of desorption--adsorption stages the removal efficiency of nitrate and phosphate decreased from 78 to $62 \%$ and from 90 to $64 \%$, respectively. This indicates that the GGR activated carbon adsorbent could be reused several times and has a high adsorption capacity. Equation 20 represents the total adsorption capacity in the fixed-bed column, where $C_{0}$ is the inlet concentration $\left(\mathrm{mg} \mathrm{L}^{-1}\right), Q$ is the volumetric flow rate $\mathrm{mL} \mathrm{min}^{-1}$, and $t^{5}$ was calculated from Eq. 5. Equation 21 indicates the desorbability, where $q_{\text {total }}^{n}$ is the total adsorption amount at the $\mathrm{n}^{\text {th }}$ cycle and $q_{\text {total }}^{\text {total }}$ is the total adsorption at the $n-1$ cycle. According to Fig. $11 \mathrm{~b}$, the nitrate adsorption amount with the fresh adsorbent was $117 \mathrm{mg}$ and decreased to $84.1 \mathrm{mg}$ at the end of the fourth desorption-adsorption cycle in the fixed-bed column. The desorbability of nitrate for each desorption-adsorption cycle was between 90 and 94\%. Based on Fig. 11d, the phosphate adsorption amount with the fresh adsorbent was $105 \mathrm{mg}$ and decreased to $70 \mathrm{mg}$ at the end of the fourth desorption-adsorption cycle in the fixed-bed column. The desorbability of phosphate for each desorption-adsorption cycle was between $88-92 \%$.

$q_{\text {total }}=\frac{C_{0} Q t^{5}}{1000}$

Disorbability $\%=\frac{100 q_{\text {total }}^{n}}{q_{\text {total }}^{n-1}}, \quad n \geq 1$ 


\subsection{Comparison of adsorption capacity of GGR activated carbon with the other adsorbent}

The monolayer adsorption capacities for nitrate and phosphate onto the GGR activated carbon are compared with other adsorbents for the removal of nitrate and phosphate. Based on Table 14 GGR activated carbon has high nitrate and phosphate adsorption capacity of 142.5 , and $92.5 \mathrm{mg} \mathrm{L}^{-1}$, respectively. Thus, it could be deduced that GGR activated carbon is an exceptional adsorbent for the removal of nitrate and phosphate.

\section{Conclusion}

According to this research, the GGR activated carbon was effectively utilized for the efficient removal of nitrate and phosphate from the wastewater. The carbonization temperature of $850^{\circ} \mathrm{C}$ and $\mathrm{ZnCl}_{2}$ impregnation ratio of $1: 2$ $\left(m_{\mathrm{p}}: m_{\mathrm{ZnCl}_{2}}\right.$ ) lead to the formation of high surface area $\left(959.22 \mathrm{~m}^{2} \mathrm{~g}^{-1}\right.$ ) of GGR activated carbon. The optimum adsorbent dosage for removal of nitrate and phosphate was determined to be $4 \mathrm{~g} \mathrm{~L}^{-1}$, and $6 \mathrm{~g} \mathrm{~L}^{-1}$, respectively. According to the kinetic data, the pseudo-second-order kinetic model was a suitable correlation for the adsorption. The Langmuir isotherm provided the best fit for the experimental data. The maximum adsorption capacity was $142.5 \mathrm{mg} \mathrm{g}^{-1}$ at $308 \mathrm{~K}$ and $92.5 \mathrm{mg} \mathrm{g}^{-1}$ at $298 \mathrm{~K}$ for nitrate and phosphate, respectively. The presence of competitor ions $\left(100 \mathrm{mg} \mathrm{L}^{-1} \mathrm{HCO}_{3}^{-}+50 \mathrm{mg} \mathrm{L}^{-1} \mathrm{SO}_{4}^{2-}\right)$ reduced the maximum adsorption capacity for nitrate and phosphate by $66 \%$ and $18 \%$, respectively. The negative $\Delta G^{\circ}$ demonstrates the spontaneous nature and thermodynamic feasibility of the adsorption process. The $\Delta H^{\circ}$ was obtained to be $15.5 \mathrm{~kJ} \mathrm{~mol}^{-1}$ and $5.12 \mathrm{~kJ} \mathrm{~mol}^{-1}$ for nitrate and phosphate, respectively, revealing the endothermic nature of adsorption. The positive value of $\Delta S^{\circ}$ indicates the increased randomness at the solid/solution interface of the adsorption process. The LUB for nitrate and phosphate with an inlet concentration of $20 \mathrm{mg} \mathrm{L}^{-1}$ and a flow rate of $40 \mathrm{~mL} \mathrm{~min}^{-1}$ was determined to be $0.44 \mathrm{~cm}$, and $4.35 \mathrm{~cm}$, respectively. These amounts indicate high utilization of the GGR activated carbon bed capacity. By increasing the flow rate and inlet concentration of nitrate and phosphate, the breakthrough time decreases. The Thomas and Yoon-Nelson models were obtained to be suitable models under different conditions for the design of GGR activated carbon fixed-bed column. Moreover, the desorbability of GGR activated carbon in the fixed-bed column was studied. The adsorbed amount of nitrate and phosphate reduced from 117 to $84.1 \mathrm{mg}$, and from 105 to $70 \mathrm{mg}$, respectively, in the fourth desorption-adsorption cycle.

\section{Compliance with ethical standards}

Conflict of interest The authors declare that they have no competing interests

\section{References}

1. Mazarji M, Aminzadeh B, Baghdadi M, Bhatnagar A (2017) Removal of nitrate from aqueous solution using modified granular activated carbon. J Mol Liq 233:139-148

2. Mehrabi N, Soleimani M, Yeganeh MM, Sharififard H (2015) Parameter optimization for nitrate removal from water using activated carbon and composite of activated carbon and $\mathrm{Fe}_{2} \mathrm{O}_{3}$ nanoparticles. RSC Adv 5(64):51470-51482

3. Teimouri A, Nasab SG, Vahdatpoor N, Habibollahi S, Salavati H, Chermahini AN (2016) Chitosan/zeolite Y/nano $\mathrm{ZrO}_{2}$ nanocomposite as an adsorbent for the removal of nitrate from the aqueous solution. Int J Biol Macromol 93:254-266

4. Bozorgpour F, Ramandi HF, Jafari P, Samadi S, Yazd SS, Aliabadi M (2016) Removal of nitrate and phosphate using chitosan $/ \mathrm{Al}_{2} \mathrm{O}_{3} /$ $\mathrm{Fe}_{3} \mathrm{O}_{4}$ composite nanofibrous adsorbent: comparison with chitosan $/ \mathrm{Al}_{2} \mathrm{O}_{3} / \mathrm{Fe}_{3} \mathrm{O}_{4}$ beads. Int J Biol Macromol 93:557-565

5. Zhang $M$, Gao B, Yao $Y$, Xue $Y$, Inyang $M$ (2012) Synthesis of porous MgO-biochar nanocomposites for removal of phosphate and nitrate from aqueous solutions. Chem Eng J 210:26-32

6. Kalaruban M, Loganathan P, Shim WG, Kandasamy J, Ngo HH, Vigneswaran S (2016) Enhanced removal of nitrate from water using amine-grafted agricultural wastes. Sci Total Environ 565:503-510

7. Zhang $Y$, Song $X-L$, Huang S-T, Geng B-Y, Chang C-H, Sung IY (2014) Adsorption of nitrate ions onto activated carbon prepared from rice husk by $\mathrm{NaOH}$ activation. Desalin Water Treat 52(25-27):4935-4941

8. Lalley J, Han C, Li X, Dionysiou DD, Nadagouda MN (2016) Phosphate adsorption using modified iron oxide-based sorbents in lake water: kinetics, equilibrium, and column tests. Chem Eng J 284:1386-1396

9. Liu X, Zhang $L$ (2015) Removal of phosphate anions using the modified chitosan beads: adsorption kinetic, isotherm and mechanism studies. Powder Technol 277:112-119

10. Bhatnagar A, Ji M, Choi YH, Jung W, Lee SH, Kim SJ, Lee G, Suk H, Kim HS, Min B (2008) Removal of nitrate from water by adsorption onto zinc chloride treated activated carbon. Sep Sci Technol 43(4):886-907

11. Zhang L, Wan L, Chang N, Liu J, Duan C, Zhou Q, Li X, Wang $X$ (2011) Removal of phosphate from water by activated carbon fiber loaded with lanthanum oxide. J Hazard Mater 190(1-3):848-855

12. Song Q, Li M, Wang L, Ma X, Liu F, Liu X (2019) Mechanism and optimization of electrochemical system for simultaneous removal of nitrate and ammonia. J Hazard Mater 363:119-126 
13. Mukhopadhyay R, Adhikari T, Sarkar B, Barman A, Paul R, Patra AK, Sharma PC, Kumar P (2019) Fe-exchanged nano-bentonite outperforms $\mathrm{Fe}_{3} \mathrm{O}_{4}$ nanoparticles in removing nitrate and bicarbonate from wastewater. J Hazard Mater 379:141-152

14. Maneerung T, Liew J, Dai Y, Kawi S, Chong C, Wang C-H (2016) Activated carbon derived from carbon residue from biomass gasification and its application for dye adsorption: kinetics, isotherms and thermodynamic studies. Biores Technol 200:350-359

15. Xiong W, Tong J, Yang Z, Zeng G, Zhou Y, Wang D, Song P, Xu R, Zhang C, Cheng M (2017) Adsorption of phosphate from aqueous solution using iron-zirconium modified activated carbon nanofiber: performance and mechanism. J Colloid Interface Sci 493:17-23

16. Afkhami A, Madrakian T, Karimi Z (2007) The effect of acid treatment of carbon cloth on the adsorption of nitrite and nitrate ions. J Hazard Mater 144(1-2):427-431

17. Dobrowolski R, Otto M (2010) Study of chromium(VI) adsorption onto modified activated carbons with respect to analytical application. Adsorption 16(4-5):279-286

18. Shamsuddin MS, Yusoff NRN, Sulaiman MA (2016) Synthesis and characterization of activated carbon produced from kenaf core fiber using $\mathrm{H}_{3} \mathrm{PO}_{4}$ activation. Procedia Chem 19:558-565

19. Gupta VK, Fatima A, Faridi U, Negi AS, Shanker K, Kumar JK, Rahuja N, Luqman S, Sisodia BS, Saikia D (2008) Antimicrobial potential of Glycyrrhiza glabra roots. J Ethnopharmacol 116(2):377-380

20. Mohammadi SZ, Hamidian H, Moeinadini Z (2014) High surface area-activated carbon from Glycyrrhiza glabra residue by $\mathrm{ZnCl}_{2}$ activation for removal of $\mathrm{Pb}(\mathrm{II})$ and $\mathrm{Ni}(\mathrm{II})$ from water samples. J Ind Eng Chem 20(6):4112-4118

21. Mohammadi-Moghadam F, Amin MM, Momenbeik F, Nourmoradi $\mathrm{H}$, Hatamipour MS (2013) Application of Glycyrrhiza glabra root as a novel adsorbent in the removal of toluene vapors: equilibrium, kinetic, and thermodynamic study. J Environ Public Health 2013:986083

22. Yahya MA, Al-Qodah Z, Ngah CWZ (2015) Agricultural biowaste materials as potential sustainable precursors used for activated carbon production: a review. Renew Sustain Energy Rev 46:218-235

23. Ji Hayashi, Kazehaya A, Muroyama K, Watkinson AP (2000) Preparation of activated carbon from lignin by chemical activation. Carbon 38(13):1873-1878

24. Kilpimaa S, Runtti H, Kangas T, Lassi U, Kuokkanen T (2015) Physical activation of carbon residue from biomass gasification: novel sorbent for the removal of phosphates and nitrates from aqueous solution. J Ind Eng Chem 21:1354-1364

25. Ahmad AA, Hameed BH (2010) Fixed-bed adsorption of reactive azo dye onto granular activated carbon prepared from waste. J Hazard Mater 175(1-3):298-303

26. Sulaymon AH, Ahmed KW (2007) Competitive adsorption of furfural and phenolic compounds onto activated carbon in fixed bed column. Environ Sci Technol 42(2):392-397

27. Dwivedi CP, Sahu JN, Mohanty CR, Mohan BR, Meikap BC (2008) Column performance of granular activated carbon packed bed for $\mathrm{Pb}$ (II) removal. J Hazard Mater 156(1-3):596-603

28. Sotelo JL, Rodríguez A, Álvarez S, García J (2012) Removal of caffeine and diclofenac on activated carbon in fixed bed column. Chem Eng Res Des 90(7):967-974

29. Gundogdu A, Duran C, Senturk HB, Soylak M, Imamoglu M, Onal $Y$ (2013) Physicochemical characteristics of a novel activated carbon produced from tea industry waste. J Anal Appl Pyrol 104:249-259

30. Ketcha JM, Dina DJD, Ngomo HM, Ndi NJ (2012) Preparation and characterization of activated carbons obtained from maize cobs by zinc chloride activation. Chem Sci Int J 2:136-160
31. Amano Y, Misugi Y, Machida M (2012) Adsorptive behavior of phosphate onto activated carbons varying surface physicochemical properties. Sep Sci Technol 47(16):2348-2357

32. Namasivayam C, Sangeetha D (2004) Equilibrium and kinetic studies of adsorption of phosphate onto $\mathrm{ZnCl}_{2}$ activated coir pith carbon. J Colloid Interface Sci 280(2):359-365

33. Liu P, Zhang H, Xiang H, Yan Y (2016) Adsorption separation for high purity propane from liquefied petroleum gas in a fixed bed by removal of alkanes. Sep Purif Technol 158:1-8

34. Nainamalai M, Palani M, Soundarajan B, Jss AE (2018) Decolorization of synthetic dye wastewater using packed bed electro-adsorption column. Chem Eng Process Process Intensif 130:160-168

35. Katal R, Baei MS, Rahmati HT, Esfandian H (2012) Kinetic, isotherm and thermodynamic study of nitrate adsorption from aqueous solution using modified rice husk. J Ind Eng Chem 18(1):295-302

36. Araújo CST, Almeida ILS, Rezende HC, Marcionilio SMLO, Léon $J \mathrm{~J}$, de Matos TN (2018) Elucidation of mechanism involved in adsorption of $\mathrm{Pb}$ (II) onto lobeira fruit (Solanum lycocarpum) using Langmuir, Freundlich and Temkin isotherms. Microchem J 137:348-354

37. Demiral H, Gündüzoğlu G (2010) Removal of nitrate from aqueous solutions by activated carbon prepared from sugar beet bagasse. Biores Technol 101(6):1675-1680

38. Schick J, Caullet P, Paillaud J-L, Patarin J, Mangold-Callarec C (2010) Batch-wise nitrate removal from water on a surfactant-modified zeolite. Microporous Mesoporous Mater 132(3):395-400

39. Köse TE, Kıvanç B (2011) Adsorption of phosphate from aqueous solutions using calcined waste eggshell. Chem Eng J 178:34-39

40. Nazari G, Abolghasemi H, Esmaieli M, Pouya ES (2016) Aqueous phase adsorption of cephalexin by walnut shell-based activated carbon: a fixed-bed column study. Appl Surf Sci 375:144-153

41. Pavia DL, Lampman GM, Kriz GS, Vyvyan JA (2008) Introduction to spectroscopy. Cengage Learning, Stamford

42. Teng H, Yeh T-S (1998) Preparation of activated carbons from bituminous coals with zinc chloride activation. Ind Eng Chem Res 37(1):58-65

43. Tahmasebi-Boldaji R, Hatamipour M-S, Khanahmadi M, Sadeh $P$, Najafipour I (2019) Ultrasound-assisted packed-bed extraction of hypericin from Hypericum perforatum L. and optimization by response surface methodology. Ultrason Sonochem 57:89-97

44. Khalil AME, Eljamal O, Amen TWM, Sugihara Y, Matsunaga N (2017) Optimized nano-scale zero-valent iron supported on treated activated carbon for enhanced nitrate and phosphate removal from water. Chem Eng J 309:349-365

45. Namasivayam C, Sangeetha D (2005) Kinetic studies of adsorption of thiocyanate onto $\mathrm{ZnCl}_{2}$ activated carbon from coir pith, an agricultural solid waste. Chemosphere 60(11):1616-1623

46. Chen J, Wu H, Qian H, Gao Y (2017) Assessing nitrate and fluoride contaminants in drinking water and their health risk of rural residents living in a semiarid region of Northwest China. Expo Health 9(3):183-195

47. Howladar MF, AI Numanbakth MA, Faruque MO (2018) An application of water quality index (WQI) and multivariate statistics to evaluate the water quality around Maddhapara Granite Mining Industrial Area, Dinajpur, Bangladesh. Environ Syst Res 6(1):13

48. Nunell GV, Fernández ME, Bonelli PR, Cukierman AL (2012) Conversion of biomass from an invasive species into activated carbons for removal of nitrate from wastewater. Biomass Bioenergy 44:87-95

49. Halajnia A, Oustan S, Najafi N, Khataee AR, Lakzian A (2013) Adsorption-desorption characteristics of nitrate, phosphate and sulfate on $\mathrm{Mg}-\mathrm{Al}$ layered double hydroxide. Appl Clay Sci $80: 305-312$ 
50. Manjunath SV, Kumar M (2018) Evaluation of single-component and multi-component adsorption of metronidazole, phosphate and nitrate on activated carbon from Prosopıs julıflora. Chem Eng J 346:525-534

51. He H, Zhang N, Chen N, Lei Z, Shimizu K, Zhang Z (2019) Efficient phosphate removal from wastewater by MgAl-LDHs modified hydrochar derived from tobacco stalk. Bioresour Technol Rep 8:100348

52. Viglašová $E$, Galamboš $M$, Danková $Z$, Krivosudský $L$, Lengauer CL, Hood-Nowotny R, Soja G, Rompel A, Matík M, Briančin J
(2018) Production, characterization and adsorption studies of bamboo-based biochar/montmorillonite composite for nitrate removal. Waste Manag 79:385-394

Publisher's Note Springer Nature remains neutral with regard to jurisdictional claims in published maps and institutional affiliations. 